\title{
Review Article \\ Exosomes: A Paradigm in Drug Development against Cancer and Infectious Diseases
}

\author{
Mohammad Oves $\mathbb{D}^{1}{ }^{1}$ Huda A. Qari, ${ }^{1,2}$ Nadeen M. Felemban, ${ }^{1}$ \\ Aftab Aslam Parwaz Khan $\left(\mathbb{D},{ }^{3}\right.$ Mohd Rehan, ${ }^{4}$ Shams Tabrez, ${ }^{4}$ Faheem Ahmed, ${ }^{5}$ \\ Ashanul Haque, ${ }^{6}$ Mohd Shahnawaz Khan, ${ }^{7}$ Javed M. Khan, ${ }^{8}$ Fohad M. Husain $\left(\mathbb{D},{ }^{8}\right.$ \\ Afzal Hussain, ${ }^{9}$ Mohiuddin Khan Warsi, ${ }^{10}$ and Iqbal I. M. Ismail ${ }^{1,11}$ \\ ${ }^{1}$ Center of Excellence in Environmental Studies, King Abdulaziz University, P.O. Box 21589, Jeddah, Saudi Arabia \\ ${ }^{2}$ Department of Biological Science, King Abdulaziz University, P.O. Box 21589, Jeddah, Saudi Arabia \\ ${ }^{3}$ Center of Excellence for Advanced Materials Research and Chemistry Department, King Abdulaziz University, \\ P.O. Box 21589, Jeddah, Saudi Arabia \\ ${ }^{4}$ King Fahd Medical Research Center, King Abdulaziz University, Jeddah 21589, Saudi Arabia \\ ${ }^{5}$ College of Science \& General Studies, Alfaisal University, Riyadh, Saudi Arabia \\ ${ }^{6}$ Department of Chemistry, College of Science, Sultan Qaboos University, P.O. Box 36, 123 Muscat, Oman \\ ${ }^{7}$ Protein Research Chair, Department of Biochemistry, College of Sciences, King Saud University, Riyadh, Saudi Arabia \\ ${ }^{8}$ Department of Food Science and Nutrition, Faculty of Food and Agricultural Sciences, King Saud University, \\ P.O. Box 2460, Riyadh 11451, Saudi Arabia \\ ${ }^{9}$ Department of Pharmacognosy, King Saud University, P.O. Box 2460, Riyadh 11451, Saudi Arabia \\ ${ }^{10}$ Department of Biochemistry, Faculty of Science, University of Jeddah, Jeddah, Saudi Arabia \\ ${ }^{11}$ Department of Chemistry, Faculty of Science, King Abdulaziz University, Jeddah, Saudi Arabia
}

Correspondence should be addressed to Mohammad Oves; owais.micro@gmail.com

Received 27 July 2017; Revised 14 November 2017; Accepted 25 December 2017; Published 26 April 2018

Academic Editor: Stefano Bellucci

Copyright (C) 2018 Mohammad Oves et al. This is an open access article distributed under the Creative Commons Attribution License, which permits unrestricted use, distribution, and reproduction in any medium, provided the original work is properly cited.

Extracellular vesicles are small single lipid membrane entity secreted by eukaryotic and prokaryotic cells and play an important role in intercellular signaling and nutrient transport. The last few decades have witnessed a plethora of research on these vesicles owing to their ability to answer many hidden facts at the supramolecular level. These extracellular vesicles have attracted the researchers because they act as shuttle agents to transfer biomolecules/drugs between cells. Recently, studies have shown the application of exosomes in tumor therapy and infectious disease control. The present review article shows the importance of exosomes in cancer biology and infectious disease diagnoses and therapy and provides comprehensive account of exosomes biogenesis, extraction, molecular profiling, and application in drug delivery.

\section{Introduction}

Extracellular vesicles are cell membrane-derived small entity. In general, these are ubiquitously found in all organisms and scattered in all types of biofluids. These are multifunctional units that act as a carrier of cellular communication as well as help in removing cellular garbage. Extracellular vesicle cargo protein, lipid, nucleic acids, or RNA from mother cells to distant tissue cells through the support of biofluids and transfer the information [1]. Earlier, extracellular vesicles were considered as an insignificant bioentity generated by the cell during its lifetime. However, in the last few decades, extracellular vesicles have generated significant interest among the scientific community as they have been found to be associated with many diseases. Recent research works demonstrate that the extracellular vesicles have potential to act as naturally 
occurring drug-delivery vehicles and can find application in several diseases including cancers. This is due to their innate biocompatibility, unique capability for targeted delivery, and ability to reach remotely located recipient cells. Number of the findings demonstrated that membrane-derived vesicles are important for diagnostic and therapeutic purposes for different diseases, including cancer, infectious diseases, cardiovascular diseases, neurodegenerative diseases, and pregnancy [2]. Its application depends on the biogenesis and size of the entities; it could be classified into exosomes, microvesicles, apoptotic bodies, and oncosomes (Figure 1). Most of the exosomes are small size extracellular vesicles, ranging between 40 and $120 \mathrm{~nm}$ and are created by the fusion of an intracellular multivesicular body with the cell membrane. However, less than $40 \mathrm{~nm}$ vesicles were also detected by subdiffraction imaging and fluorescent probe during a real-time study of exosomes trafficking in living cells [3, 4]. Microvesicles are generated by normal cell and its size ranges from 100 to $1000 \mathrm{~nm}$ and apoptotic bodies' sizes up to $5 \mu \mathrm{m}$ are generated by apoptotic cell. Similarly, oncosomes are the largest vesicles, their size ranges from 1 to $5 \mu \mathrm{m}$, and they are secreted by cancer cells $[1,5]$.

Among all above-mentioned vesicles, exosomes have attracted more interest among the researchers, owing to their intriguing capabilities like mediating cell-to-cell communication. Intercellular communication is an important process to maintain homeostasis in multicellular systems. The dysregulation of communication pathways have been associated with the cancer development and progression [48]. Therefore, the development of novel anticancer treatments will strongly depend on improving our understanding of the cellular interactions between cancer cells and other cells. Cellular communication takes place between cells through gap junctions, adhesion molecules, and nanotubes; also, it can be via soluble communication signals like growth factors, cytokines, tumor, and non-tumor-derived hormones. To date, several researches have showed a positive correlation between carcinogenesis/metastasis/drug resistance/bacterial infection and the concentration of exosomes $[49,50]$. Logozzi et al. have also quantified the exosomes of plasma of melanoma patient and healthy donors by housekeeping proteins and caveolin1 marker and found significant higher exosome in plasma of melanoma patient and concluded that exosomes have direct relation in malignant progression [51]. Recently, VanDeun et al. have developed a knowledge base EV-TRACK for enhancement of transparency and reproducibility of vesicles research road map [52]. Based on these notions, we herein present a brief review on the importance of exosomes in drug delivery in both cancerous and noncancerous ailments. Additionally, we have also discussed the basic function of exosomes in the human body, molecular profiling, and its characteristics.

\section{Exosomes Uniqueness and Natural Existence}

Initially, researchers observed human plasma fraction has coagulant properties as "platelet dust," and, later on, the fraction was characterized as microparticles [53]. Trams et al. made the first description of exosomes in 1981 [54]. Johnstone and coauthors have also termed the extracellular vesicles as exosomes. They had isolated exosomes from sheep reticulocytes during reticulocytes maturation into erythrocytes [55]. Whenever cells enter apoptosis, irregular shaped apoptotic vesicles are generated with size 50-5000 $\mathrm{nm}$ [56]. These vesicles may contain histones, DNA, and RNA molecules and are immediately cleared by the immune system (macrophages) in response to their apoptotic signaling [57]. In contrast, microvesicles originate by budding and fission of the cellular plasma membrane into extracellular space. These vesicles are more homogeneously shaped, smaller than the apoptotic bodies in size ranging from 50 to $1000 \mathrm{~nm}$ and rich in specific proteins and lipids [58]. The major population of extracellular vesicles is identified as exosome by size less than $100 \mathrm{~nm}$ in diameter. Most of the mammalian cells like neurons and immune cells secrete exosomes and cancer cells also secrete greater amounts of exosomes. Interestingly, Gram-negative bacteria also produce outer membrane vesicles during normal growth, which contain bioactive proteins and it has diverse biological functions. The bacterial outer membrane vesicles are small ball-shaped structures with a size range from 20 to $250 \mathrm{~nm}$ in diameter. Mayrand and Grenier have described the formation, growth conditions, isolation, composition, and biological activities of bacterial outer membrane vesicles [59]. Similarly, Kulp and Kuehn investigated the natural sources, characteristics, biological functions, and biogenesis of vesicles from bacteria and revealed the vesicle secretion through the distal effect of membrane molecules during environmental interaction [60]. Moreover, it has been reported that bacteria can also secrete outer membrane vesicles during their normal activities. Gram-negative bacteria that are able to secrete outer membrane vesicles during normal growth include E. coli, $N$. meningitis, Sh. flexneri, $P$. aeruginosa, and $H$. pylori [61-64]. In addition, it has been reported that fungi and eukaryotic parasite can also secrete extracellular vesicles [65].

Exosomes are membrane-derived vesicles actively secreted by mammalian cell particularly immune cells, such as macrophages [66], dendritic cells, $T$ cells $[67,68]$, and $B$ cells [69]. Exosomes are also secreted by mesenchymal stem cells [70], epithelial [71] and endothelial cells [72], and cancer cells [42]. Li et al. have reported the secretion of exosomes from intestinal epithelial cells, fibroblasts, mastocytes, antigen presenting cells, platelets, hepatocytes, and lymphocyte [73]. In addition, exosomes have also been identified in different body fluids, including human saliva, serum, breast milk [74], CSF [75], urine [76], and semen [77].

\section{Structure and Contents}

In 2014, the International Society for Extracellular Vesicles (ISEV) has reported the presence of exosomes-associated surface markers and the absence of nonexosomal proteins for the characterization of exosomes. The exosomes-associated surface markers include Alix, TSG101, tetraspanins (CD9, CD63, and CD81), flotillin 1, cell adhesion molecules (CAM), and integrins [79]. Exosomes consist of a lipid bilayer membrane and are characterized by a size of $50-100 \mathrm{~nm}$ in diameter, and they have "cup" or "dish" shaped morphology when 
Cell membrane generating products

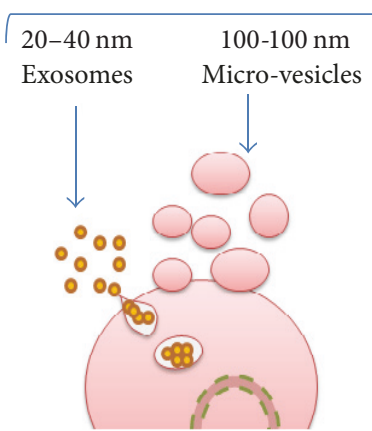

Normal cell

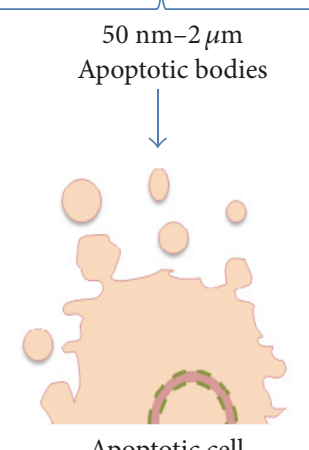

Apoptotic cell

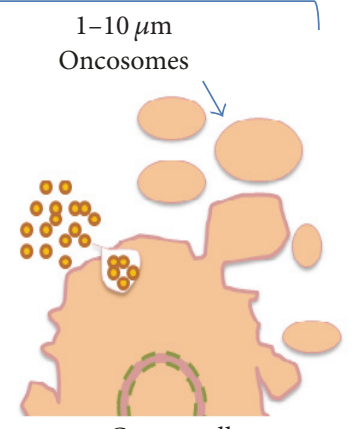

Cancer cell

Figure 1: Different types of extracellular vesicles (EVs) produced by normal and diseased cells.

analyzed by electron microscopy and are enriched with certain protein markers such as tetraspanins [42]. Moreover, its presence is also determined by density gradient, it has density $\sim 1.13-1.19 \mathrm{~g} / \mathrm{ml}$ and membrane rich in lipids like ceramide, cholesterol, and sphingolipids [80]. ExoCarta is an exosomes database, which was created in 2008 to collect and classify the identified exosomal proteins and RNA molecules. The resource is web-based (http://www.exocarta.org) and freely available to the scientific community [81]. To this date, they have identified 9769 proteins, 3408 mRNAs, and 2838 miRNAs by independent examinations in exosomes from different species and tissues. In addition, the membrane structure of Gram-negative envelope consists of two membranous structures: the inner one (IM) and the outer membrane $(\mathrm{OM})$ and these two membranes are separated by the periplasm. The outer layer of the OM is composed of lipopolysaccharide (LPS), whereas the inner layer and both layers of the IM are composed of phospholipids. The periplasm is a gel-like layer that contains a thin layer of peptidoglycan $(4 \mathrm{~nm}$ thick) [60]. Therefore, the secreted vesicles are composed of lipopolysaccharide, periplasm, and phospholipids [82].

\section{Biogenesis, Release, and Uptake}

Membrane vesicles play diverse roles in cellular communications in both prokaryotic and eukaryotic cells, while Gram-negative bacteria secrete outer membrane vesicles and eukaryotic cells secret microvesicles for cellular contact. Mechanisms of bacterial vesicle biogenesis and the pathophysiological roles are still not defined clearly. However, vesicles secreted by different types of cells may have several similarities in the biogenesis and functions in different biological systems. Zhou et al. [83] have suggested that the biogenesis of Gram-negative bacteria derived vesicles could be because of cell wall turnover during growth, which causes a turgor on the outer membrane, eventually causing the outer membrane to bulge and then bleb. It is excised and removed from the peptidoglycan layer of the cell wall. Independent experimental studies also demonstrated that membrane vesicles are generated as a result of cell wall turnover in Gramnegative bacteria [83, 84]. However, Wensink and Witholt
[85] have described a hypothesis for the biogenesis of Gramnegative bacteria derived vesicles. They suggested that the blebbing of outer membrane might occur in response to a high rate outer membrane synthesis in comparison to peptidoglycan.

On the other hand, the process of exosome biogenesis in human samples has been clearly defined in several studies, which includes four sequential stages: (1) initiation, (2) endocytosis, (3) multivesicular bodies, and (4) exosomes secretion [86]. Previous studies have suggested that exosomes are derived from the multivesicular bodies sorting pathway. Exosomes originate by inward budding into large multivesicular bodies in the cell cytoplasm, and then these bodies fuse with the plasma membrane leading to exosome secretion into the extracellular space. Moreover, either the endosomalsorting complex is required for transport signaling or the sphingolipid ceramide pathway [87] regulates this process. In response to vesicular accumulation, the multivesicular bodies will be either sorted to be degraded by lysosome or released into the extracellular space for exosome secretion through the process of exocytosis. The exosomal cargo, including proteins, lipids, and RNA/DNA molecules, is all packed into the exosomes during this process; the exosomal contents may vary according to the parent cell type. Previous studies have reported that a number of proteins play a role in regulating exosomes secretion pathway. Ostrowski et al. have shown that Rab GTPase machinery can regulate exosome secretion, in which Rab27a and Rab27b proteins can affect the size and localization of multivesicular bodies [88]. Other studies have demonstrated that the exosome secretion can be affected by different factors. For instance, the secretion will be increased in response to intracellular $\mathrm{Ca}^{+2}$ accumulation [89]. Another factor that would affect the exosome release is the cellular $\mathrm{pH}$. When the $\mathrm{pH}$ of the microenvironment is low, exosomes secretion and uptake by target cells increase as well. In a recent study, it was observed that low $\mathrm{pH}$ conditions have significant effect on the exosomes expression of the cancerous cells. When prostate cancer cell lines were cultured at both low $\mathrm{pH}$ and $7.4 \mathrm{pH}$, then exosomes were more predominant at low $\mathrm{pH}$ cultured condition. Similarly, tumor-released exosomes are able to transfer their content to target cells by 
membrane-to-membrane fusion and this is much favored by microenvironmental conditions such as low $\mathrm{pH}$. The delivery of exosomal cargo for uptake of their target cells can occur by one of the following ways: (1) receptor-ligand interaction; (2) direct fusion of exosomes with the plasma membrane of the recipient cell, which leads to releasing the exosomal content into the cellular cytoplasm; (3) endocytosis by phagocytosis.

\section{Extraction of Exosomes}

The abnormality in proteins/enzymes or nucleic acid function is an indication of cellular dysregulation or diseases. Identification of such dysfunctions could significantly change the outcome and condition of a patient. The biophysical characterization/screening of exosomes in biofluids are an emerging area of research, as they contain information from the mother cells. It has been demonstrated that the concentration of exosomes is directly related to the health condition of a person [90]. In such situations, the development of novel methods for isolation, molecular profiling, and concentration determination of exosomes would not only enhance the knowledge at supramolecular level but also help in delineating many hidden questions related to deadly diseases like cancer. For this purpose, several classical and modern methods for extraction, isolation, and characterization from different biomatrices are available. It must be noted that exosomes isolation methods to date only enable enrichment but not distinct separation of these extracellular vesicles subpopulations [1]. Table 1 depicts some general approaches and mechanisms used for the isolation of exosomes [6-13].

Recently, ultracentrifugation was used for exosomes isolation in combination with the sucrose gradient and immunedependent isolation such as Magnetic Activated Cell Sorting (MACS) [91]. Deun et al. have suggested a comparative evaluation of exosome isolation protocols: (i) OptiPrep ${ }^{\mathrm{TM}}$ density gradient centrifugation which outperforms ultracentrifugation and (ii) ExoQuick and total exosomes isolation and precipitation in terms of purity, quantity, and purity and their impact on downstream omics approach for biomarker development [91].

Differential ultracentrifugation involves applying different levels of centrifugal force on a solution containing exosomes such as biological fluids or conditioned cell culture media [92]. Starting from low speed centrifugation, which is necessary initially to remove cells and large cellular debris, then, the resulting supernatant is centrifuged at 10,000$20,000 \times \mathrm{g}$ in order to remove large debris and intact organelles. Lastly, the supernatant is again subjected to a high-speed centrifugation $(100,000-150,000 \times \mathrm{g})$ in order to achieve a pellet exosomes. Therefore, this method precipitates not only the exosomes but also other membrane vesicles, proteins, and/or protein-RNA aggregates. In general, the density of exosomes is different from the contaminants; it can be separated by using sucrose density gradient with centrifugation. This technology is more efficient than ultracentrifugation while it is requiring more centrifugation time up to 62 to $90 \mathrm{~h}$ [52]. In addition to this, immune-affinity chromatography and size exclusion chromatography are also normally used for the extraction of exosomes. In the antibody-dependent method, it is covalently attached to exosomal surface markers like TSG 101 or tetraspanins and nontarget particles remain unbound. When the unbounded particles are removed then washing the stationary phase with a low $\mathrm{pH}$ buffer may collect the bounded particles. This process is efficient and provides pure exosomes compared to other size/density-dependent methods. Likewise, Kalra et al. have confirmed OptiPrep density gradient method was more efficient to isolate exosomes without plasma proteins [94].

Size exclusion chromatography contains different size components which separate solutions according to their size. In addition, the SEC is using a gravity flow for separation, to maintain the vesicle structure, integrity, and biological activity of exosomes [12]. This technology has high sensitivity and excellent reproducibility, because it is using gravity flow for separation which makes it time-consuming if it could be combined with ultracentrifugation; then high isolation rate can be achieved in less time [94]. Moreover, commercial kits are also available for exosomal extraction process. Besides these two techniques, polymer precipitation and microfluidic technologies, are also effective methods to be used for exosomal isolation as an alternative to ultracentrifugation; these methods were described in detail by Batrakova et al. [93]. ExoQuick-TC kit is the most common commercial polymer precipitation-based method for exosomes extraction. This method is employed to isolate viruses and other macromolecules by using polyethylene glycol (PEG). On the other hand, microfluidic-based techniques use smaller volumes of starting solution and provide more pure exosomal isolate within a short time [95]. Moreover, these technologies have been used for diagnostic purposes because of their low yield and high sensitivity. This method depended on one of the following techniques: (a) immunoaffinity, (b) sieving, and (c) trapping exosomes, which was described by Batrakova et al. [93].

\section{Molecular Profiling of Exosomes}

Molecular profiling of exosomes obtained from different sources is an important step. Exosomes are characterized according to their biochemical properties (size, protein, and lipid content) using different methods [96] like Western Blotting, transmission electron microscope (TEM), nanoparticle tracking analysis (NTA) [9], dynamic light scattering (DLS), mass spectrometry (MS), flow cytometry $[95,96]$, tunable elastomeric pore sensing, [97] and microfluidics [98] but these are not limited. The detection and profiling are often hindered by the requirements of high purity and large sample amount. To circumvent these issues, several new, sensitive, and selective methodologies based on surface plasmon resonance (SPR), fluorescence fluctuation spectroscopy (FFS), and so forth have been applied in several reports in Table 2 [14-19]. Among these, SPR is the most popular label-free, real-time sensing technique [99]. Vogel and coworkers have developed a label-free SPR based methodology for the detection of exosomes derived from breast cancer cell lines (MCF7, BT-474, and MDA-MB-231) [15]. They reported immunosensor surface has the ability to identify various exosomes as well as exosomal biomarkers $[98,100]$. The molecular profiling results of exosomes have indicated the selective and 
TABLE 1: Exosomes isolation methods and mechanisms with specificity and demerits.

\begin{tabular}{|c|c|c|c|c|c|}
\hline Methods & Steps & Mechanism & Specificity & Demerit & Ref. \\
\hline $\begin{array}{l}\text { Differential } \\
\text { centrifugation }\end{array}$ & $\begin{array}{l}\text { (i) } 300 \times \mathrm{g}(10 \mathrm{~min}) \\
\text { (ii) } 1000 \times \mathrm{g} \text { to } 20000 \times \mathrm{g} \\
(30 \mathrm{~min}) \\
\text { (iii) } 100,000 \times \mathrm{g}(60 \mathrm{~min})\end{array}$ & $\begin{array}{l}\text { Based on centrifugal } \\
\text { force }\end{array}$ & $\begin{array}{l}\text { Common method to } \\
\text { isolate exosomes from } \\
\text { biological fluids }\end{array}$ & $\begin{array}{l}\text { Yield lower when } \\
\text { sample is } \\
\text { viscous }\end{array}$ & [6] \\
\hline Density gradient & $\begin{array}{l}\text { (i) } 30 \% \text { sucrose gradient } \\
\text { (ii) Differential } \\
\text { centrifugation }\end{array}$ & $\begin{array}{c}\text { Based on centrifugal } \\
\text { force and density } \\
\text { gradient }\end{array}$ & $\begin{array}{l}\text { Separate low-density } \\
\text { exosomes from high } \\
\text { density contaminants } \\
\text { and vesicles }\end{array}$ & $\begin{array}{l}\text { Sensitivity high with } \\
\text { centrifugation time }\end{array}$ & [7] \\
\hline $\begin{array}{l}\text { Size exclusion } \\
\text { chromatography }\end{array}$ & $\begin{array}{l}\text { (i) Sample applied on } \\
\text { column packed with } \\
\text { specific designed porous } \\
\text { beads that allow elation } \\
\text { only exosomes, without } \\
\text { centrifugal force }\end{array}$ & $\begin{array}{l}\text { Based on porosity of } \\
\text { materials }\end{array}$ & $\begin{array}{l}\text { Centrifugal force } \\
\text { sensitive vesicles } \\
\text { isolate this method } \\
\text { and specific beads } \\
\text { used for specific size. } \\
\text { multiple biological } \\
\text { samples can run } \\
\text { together in this } \\
\text { method }\end{array}$ & $\begin{array}{l}\text { Long time taking } \\
\text { procedure }\end{array}$ & {$[8]$} \\
\hline Filtration & $\begin{array}{l}\text { (i) Exosomes separate } \\
\text { from the high molecular } \\
\text { weight proteins and fatty } \\
\text { acids }\end{array}$ & $\begin{array}{l}\text { Based on membrane } \\
\text { materials and porosity }\end{array}$ & $\begin{array}{c}\text { Easily separate the } \\
\text { soluble molecules and } \\
\text { small particles from } \\
\text { exosomes }\end{array}$ & $\begin{array}{l}\text { Exosomes attached } \\
\text { with membranes and } \\
\text { lost the yield and } \\
\text { original size }\end{array}$ & [9] \\
\hline $\begin{array}{l}\text { Polymer-based } \\
\text { precipitation }\end{array}$ & $\begin{array}{l}\text { (i) Biological fluid } \\
\text { mixing with polymer } \\
\text { (ii) Incubation till } \\
\text { precipitation } \\
\text { (iii) Centrifugation at } \\
\text { low speed. } \\
\text { (vi) Resuspend in PBS }\end{array}$ & $\begin{array}{c}\text { Based on polymer } \\
\text { materials and } \\
\text { precipitation }\end{array}$ & $\begin{array}{l}\text { The advantages of } \\
\text { precipitation include } \\
\text { the mild effect on } \\
\text { isolated exosomes and } \\
\text { usage of neutral pH }\end{array}$ & $\begin{array}{l}\text { Polymer-based } \\
\text { precipitation and } \\
\text { co-isolation of } \\
\text { contaminants, like } \\
\text { lipoproteins. In the } \\
\text { presence of polymer } \\
\text { material, not } \\
\text { compatible with } \\
\text { downstream analysis }\end{array}$ & {$[10,11]$} \\
\hline $\begin{array}{l}\text { Immunological } \\
\text { separation }\end{array}$ & $\begin{array}{l}\text { (i) Magnetic beads } \\
\text { bound to the specific } \\
\text { antibodies } \\
\text { Example: ELISA-based } \\
\text { separation method }\end{array}$ & $\begin{array}{l}\text { Based on antibody } \\
\text { receptor interaction }\end{array}$ & $\begin{array}{c}\text { Methods for } \\
\text { characterization and } \\
\text { quantification of } \\
\text { protein involve in } \\
\text { selective subtypes of } \\
\text { exosomes }\end{array}$ & $\begin{array}{l}\text { Method is not } \\
\text { applicable for large } \\
\text { volumes }\end{array}$ & [7] \\
\hline Isolation by sieving & $\begin{array}{l}\text { (i) Sample sieving via a } \\
\text { membrane } \\
\text { (ii) Perform filtration } \\
\text { with pressure } \\
\text { (iii) electrophoresis }\end{array}$ & $\begin{array}{l}\text { Based on sieving size } \\
\text { and pressure }\end{array}$ & $\begin{array}{l}\text { Short separation time } \\
\text { with high purity of } \\
\text { exosomes }\end{array}$ & Low recovery rate & {$[12]$} \\
\hline Cell sorting & $\begin{array}{l}\text { (i) Sample incubation } \\
4 \mathrm{~h} \text { with } \\
\text { magnetic beads } \\
\text { (ii) centrifugation } \\
100,000 \times \mathrm{g}(60 \mathrm{~min})\end{array}$ & $\begin{array}{l}\text { Based on centrifugal } \\
\text { and magnetic force }\end{array}$ & $\begin{array}{l}\text { Short separation time } \\
\text { with high purity of } \\
\text { exosomes }\end{array}$ & Expensive and hectic & {$[13]$} \\
\hline
\end{tabular}

effective discrimination between the antigen generated by three different types of cell lines. In previous studies, the same research team has reported the molecular and dimensional profiling of exosomes by using the FFS method [100, 101]. Another SPR based method has been reported recently to determine the concentration of exosomes in solution [98]. Using surface functioned sensor with anti-CD63 antibodies, the authors detected exosomes selectively obtained from human mast cells. By this method, total mass (lipids, proteins, and nucleotides) could also be determined using a small sample volume. Despite the fact that exosome deformation hindered the study, the authors reported high accuracy $( \pm 50 \%)$ in concentration determination. An easy, efficient, and novel label-free SPR imaging (SPRi) technique in combination with antibody microarrays was reported for the quantitative determination of exosomes in cell culture supernatant (CCS) [102]. The study also showed a positive association between exosome secretion and metastatic potential in hepatocellular carcinoma cells (highly metastatic cell line secreted more exosomes than poorly metastatic ones). 
TABLE 2: Recent reported methods for molecular profiling of exosomes.

\begin{tabular}{|c|c|c|c|c|}
\hline Method & Source & Application & Explanations & Ref. \\
\hline $\begin{array}{l}\text { Combined colloidal gold } \\
\text { nanoplasmonics and } \\
\text { SPR }\end{array}$ & Serum & Oncology & $\begin{array}{l}\text { Detection at molar level, Showed presence of } \\
\text { 4-fold exosomes in MM patients than normal }\end{array}$ & [14] \\
\hline Microfluidic & Plasma & $\begin{array}{c}\text { Cancer as well as } \\
\text { non-cancerous diseases }\end{array}$ & Enhanced and minimal invasive detection, & {$[15]$} \\
\hline SPR & Serum & Oncology & $\begin{array}{l}\text { Quantification of the proportion of CREs } \\
\text { within the bulk exosome population }\end{array}$ & {$[16]$} \\
\hline NTA & Whole blood sample & Oncology & $\begin{array}{c}\text { Enriched level of MDR-1, MDR-3, } \\
\text { endophilin-A2, and PABP4 in resistance } \\
\text { prostate cancer cells (DU145) }\end{array}$ & {$[17]$} \\
\hline Metal Nanoparticle & Serum & Oncology & $\begin{array}{l}\text { Microsome and exosome detection, detection } \\
\text { of two surface markers on exosome }\end{array}$ & {$[18]$} \\
\hline Dual-wavelength SPR & Synthetic & Drug development & $\begin{array}{l}\text { Vesicles carrying marker CD63 link to not } \\
\text { greater than } 10 \% \text { of the vesicles in sample. }\end{array}$ & [19] \\
\hline
\end{tabular}

Zhu et al. developed a label-free nanoplasmonic exosome (nPLEX) assay for quantitative analysis of exosomes [105]. The method, which was based on transmission mode SPR through functionalized nanohole arrays (Figure 2(a)), has the ability to detect proteins present on the surface as well as in the lysate of exosomes. They found that a large amount of exosomes with an average diameter of $100 \mathrm{~nm}$ was secreted by the ovarian carcinoma cell lines. The selective identification of ovarian carcinoma exosomes (detection of 12 potential exosomal markers within $30 \mathrm{mins}$ ) dictates the potential of the method for diagnostic purposes (Figure 2(b)).

Proteomic analyses have been used to identify and decode the proteins associated with outer membrane vesicles. Although bacterial outer membrane vesicles are more abundant and easier to obtain than human vesicles, only few proteomic profiling instances of native outer membrane vesicles derived from bacterial strains have been reported [78, 104-107]. Previous studies described the process of Sodium dodecyl sulphate-polyacrylamide gel electrophoresis (SDS-PAGE) of outer membranes and vesicle polypeptides to identify their protein profiles [108]. In addition, exosomal RNA and proteins were also identified using RT-PCR, nucleic acid sequencing, Western Blot, or ELISA [42]. Sambrook et al. have also described the conventional agarose electrophoresis in the presence of ethidium bromide in order to detect nucleic acids in samples of vesicles derived from bacterial strain [111].

\section{Exosomes Role in Normal and Cancer Cells}

A number of studies have demonstrated the tumor-derived exosomes, which serve as biologic messengers for immune suppression and other procancer activities [64, 110, 111]. Cancer-derived exosomes play diverse roles in the tumorigenesis, tumor growth, angiogenesis, metastasis, and drug resistance [42]. During the process of tumorigenesis, normal cells are transformed into cancerous cells and subsequently secrete exosomes, which have the potential to transform the healthy cells to cancerous cells. As an example, neoplastic transformation of adipose-derived stem cells (ASCs) could be induced in response to prostate cancer cell-associated exosomes, which deliver the oncogenic proteins and mRNA molecules to recipient cells and subsequently induce tumor formation [112]. Sometimes tumor-released exosomes, expressing a reportergene, travel through the blood of xenografts ending within the germ line that in turn expressed the exosomes-delivered gene, thus supporting the idea of a key role of extracellular vesicles in somato-to-germ-line transmission of nucleic acids. In addition, it has been widely reported that tumor-derived exosomes show promoting effect on tumor growth. During tumor formation, exosome containing cell survive because it has the ability to inhibit apoptosis and promote proliferation and metastasis [113]. Similarly, in human tumor cell line derived exosomes may induce tumor-like transformation of human mesenchymal stem cells, supporting a key role of exosomes in tumor metastasis [114]. Consequently, angiogenic factors are usually present in tumor-derived exosomes, which is necessary for angiogenesis and tumor proliferation [115]. Exosomes also contain factors required for metastasis, thus enhancing migration and invasiveness of cancerous cells [116-118]. Moreover, exosomes also play a role in the development of drug resistance via different mechanisms. For example, cancer cell-derived exosomes transmit multidrug resistance $(\mathrm{MD})$ associated proteins and miRNAs to recipient cells leading to the development of resistance [119]. Another mechanism by which exosomes induce resistance is an exosomal drug efflux, in which drugs can be affixed from the cancerous cells by exosomes [120]. During cancer therapy development of intrinsic resistance against drugs happens due to acidic microenvironment and chemo resistance impairment in drug delivery. In addition to these, several studies have shown the relationship between exosome and immune system function [121]. They suggested that exosomes can interact through signaling and the exosome comes from immune cells. While melanoma cell releases extracellular vesicles expressing FasL that efficiently induces Fas-mediated apoptosis in target $\mathrm{T}$ cells, suggesting the role of tumor exosomes in tumor immune escape. Extracellular vesicles released by human colon cancer cells express that both FasL and Trail are able to induce cell death of target $\mathrm{T}$ cells through the specific pathways and that exosomes expressing these 


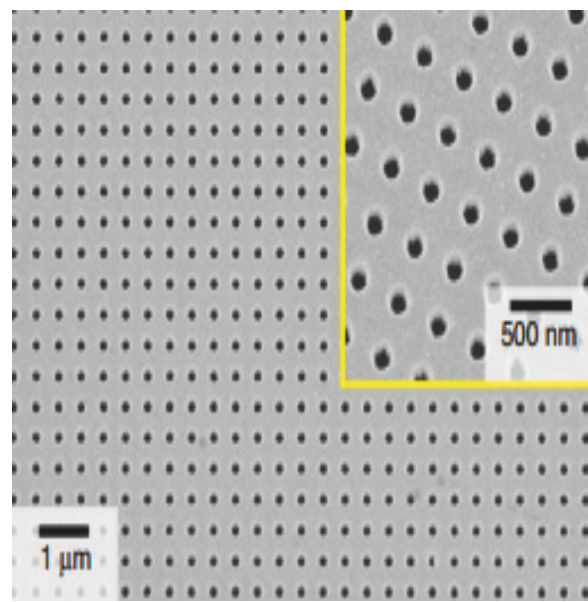

(a)

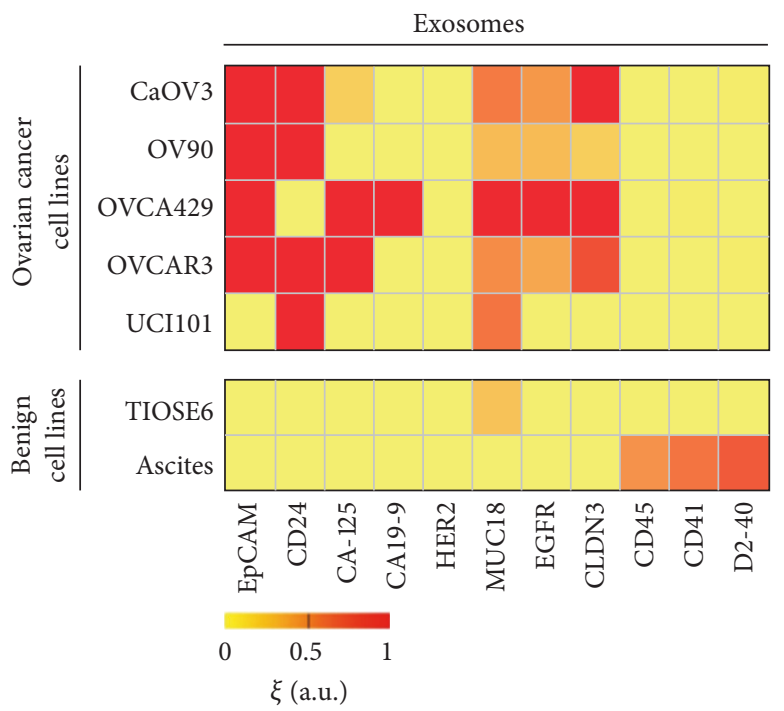

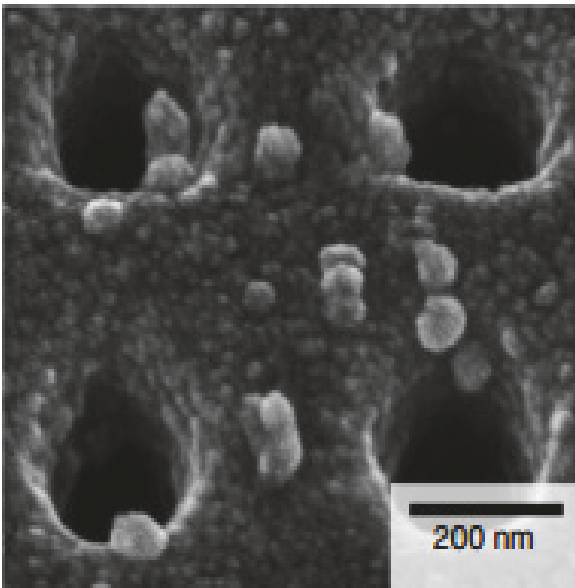

(b)

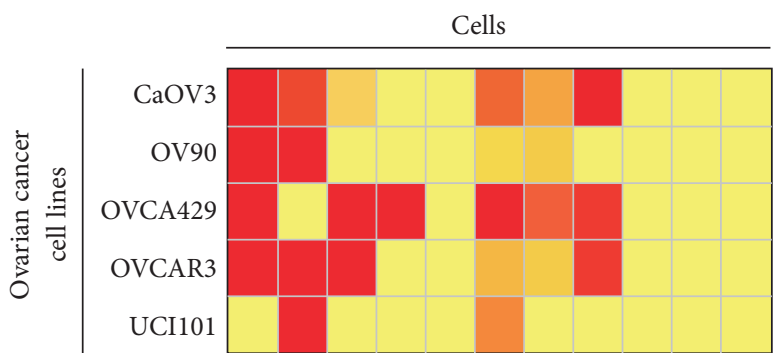

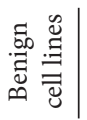

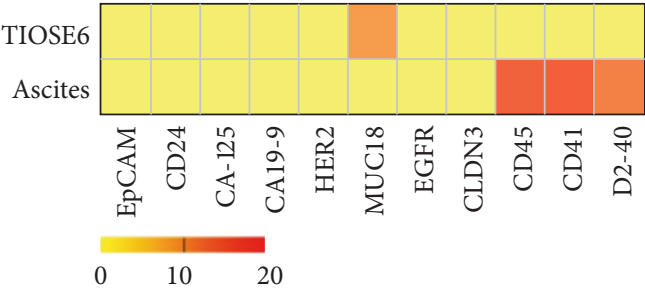

Relative MFI (a.u.)

(c)

FIGURE 2: Scanning electron microscopy image of (a) nPLEX sensor with periodic nanoholes in the range from 200 to $450 \mathrm{~nm}$ in diameter, and here (2b) exosome captured by functionalized nPLEX. (2c) EpCAM, CD24, CA19-9, CLDN3, CA-125, MUC18, EGFR, and HER2, a list of putative ovarian cancer markers; CD41 and CD45 for immune host cell markers and D2-40 a mesothelial marker for exosomes profiled left in nPLEX sensor and their parental ovarian cell lines filled in right for flow cytometer, according to Im et al. [78].

two molecules are detectable in the plasma of colon cancer patients and entirely functional in inducing $\mathrm{T}$ cell death [122]. In mammalian cells, exosomes have pro- and antiinflammatory properties depending on the type of cell origin [80]. For example, NK cells release exosomes expressing functional molecules associated with NK-cell function and the same exosomes are detectable in the plasma of healthy humans, suggesting a key role of NK-released exosomes in the control of our body homeostasis [114, 123]. However, similar findings have been reported with single cell eukaryoticderived vesicles. Zhang et al. have demonstrated that exosomes are involved in cell-to-cell contact during immune responses for tumorigenesis, infectious diseases, allergies, and autoimmune diseases [42], for example, during myocardial infractions in the presence of clusterin in exosomes obtained from pericardial fluids of patients [124]. Currently, there are two main groups of exosomes that are involved in infectious biological: (1) single-celled eukaryotic exosomes and (2) exosomes derived from infected cells. The eukaryotic single-celled pathogens such as the pathogenic fungus Cryptococcus neoformans and the protozoan parasites Leishmania major and donovani [125] secrete exosomes, which may influence the host immune system. The second group is exosomes released by mammalian cells infected with pathogenic bacteria, prion protein, and viruses [126, 127]. Previous studies have reported that bacteria can secrete outer membrane vesicles; fungi and eukaryotic parasite can also secrete extracellular vesicles [128]. Pathogen-derived exosomes carry specific virulence factors like proteins or RNA molecules, which can either spread or limit the infection depending on the pathogen and its target cells, Table 3 [20-27]. Furthermore, the potential roles of pathogen-derived vesicles 
TABLE 3: Examples of infectious disease where pathogen-derived exosomes play a role in pathogenesis.

\begin{tabular}{|c|c|c|c|}
\hline Disease causing agents & Name of disease & Exosomes role & Ref. \\
\hline Leishmania spp. & Leishmaniasis & Spread virulence factors & {$[20]$} \\
\hline HIV & AIDS & $\begin{array}{l}\text { CD4+ T cells transinfection and delivery of } \\
\text { Nef to by stander cells }\end{array}$ & {$[21]$} \\
\hline Prion protein & $\begin{array}{c}\text { Transmissible spongiform } \\
\text { encephalopathies }\end{array}$ & Virulent factors delivery to normal cells & {$[22]$} \\
\hline Cryptococcus neoformans & Cryptococcosis & $\begin{array}{l}\text { Virulence factors spread and polysaccharide } \\
\text { capsule formation }\end{array}$ & {$[23]$} \\
\hline Histoplasma capsulatum & $\begin{array}{l}\text { Ascomycota opportunistic fungal } \\
\text { pathogens }\end{array}$ & $\begin{array}{l}\text { Spread virulence factor in intracellular and } \\
\text { extracellular space and promote virulence } \\
\text { and provide stress response and fungal } \\
\text { growth }\end{array}$ & {$[24]$} \\
\hline C. Albicans, & $\begin{array}{l}\text { Oral, vaginal, and systemic } \\
\text { infections }\end{array}$ & \multirow{4}{*}{$\begin{array}{l}\text { Help in growth, Spread virulence and } \\
\text { enhance pathogenicity }\end{array}$} & \multirow{4}{*}[25]{} \\
\hline C. parapsilosis & Candidiasis & & \\
\hline S. schenckii & RTI & & \\
\hline S. cerevisiae & Rarely pathogenic & & \\
\hline Trypanosoma cruzi & & $\begin{array}{c}\text { Surface antigens spread during } \\
\text { pathogenicity with membrane vesicles }\end{array}$ & {$[26]$} \\
\hline $\mathrm{HCV}$ & Chronic HCV & v RNA transfer in normal cells & [27] \\
\hline
\end{tabular}

in infection biology are illustrated in Table 3 [20]. However, during infection pathogen derived vesicles formation is much less recognized about the molecules involved in exosomes biogenesis and secretion. In mammalian cells, the molecules that are involved in exosomes biogenesis and secretion include ESCRT protein [27], ceramide [87], Rab27 [88], Rab11 [89], and Rab35 [129]. Although a similar subset of these proteins (ESCRTs, Rab11, and Rab27) has been identified in and Leishmania exosomes [125], their role in single-celled eukaryotic exosome biogenesis and release is not clear yet. In another experimental study, Silverman et al. have suggested that HSP100 plays an important role in packaging of proteins into Leishmania exosomes [135]. Interestingly, exosome has been associated with prion related disease. Berrone et al. observed pathological prion protein from the blood of animals with a prion related disease only associated with exosomes and this was in turn associated with plasma infectivity as well [136].

\section{Exosomes from Bacteria and Its Function}

The outer membrane vesicles associated proteins have significant biological activities as mentioned in previous studies $[132,133]$. In addition, the outer membrane vesicles can mediate the secretion of both soluble and insoluble compounds (such as bacterial lipids and membrane proteins). For instance, then it allows the secretion of adhesion molecules of pathogenic bacteria. Adhesins are insoluble proteins that mediate coaggregation and these proteins are important for host tissues colonization. Another type of insoluble molecule like quinolone was secreted in outer membrane vesicles by Pseudomonas as a signal molecule, which is important for cellular communication [134]. Moreover, the bacterial exosomes are also mediating the secretion of soluble proteins in a protective complex, in which soluble molecules are part of the lumen or attached to their surface. The surface-associated soluble proteins and the periplasmic molecules within the vesicle lumen are resistant against extracellular degradations by proteases. This complexity provides the ability of membrane vesicles to protect the secreted proteins and to allow less stable molecules, to reach further destinations during their transport [135]. Kadurugamuwa and Beveridge [137] have proposed two mechanisms for delivering the soluble content of membrane vesicles to its target site. The content could be delivered either through spontaneous lysis of outer membrane vesicles and consequently content diffuses or attachment of vesicles to their target followed by proximal lysis, internalization, or fusion to deliver the content.

The outer membrane vesicles secreted by bacterial strain might contribute significantly to bacterial survival and virulence factor existence. For instance, membrane vesicles could act as a defense and resistance mechanism against both internal or external damaging agents, and thus the vesicles can eliminate these toxicants instantly [136]. In addition, vesicles are loaded with lytic enzymes and receptors, which are important for bacterial nutrient acquisition [137]. Moreover, theses vesicles are also important for nucleation and mediating the interactions of biofilm [138]. All the above-mentioned survival-related functions are important to enable the pathogenic organism to survive inside the host and eventually cause diseases. In addition, it also contains virulence factors such as an active toxin, which can be delivered into host cells by different mechanisms $[139,140]$.

\section{Exosomes-Mediated Drug Delivery}

Recently, evidences of natural exosomes-mediated drug delivery are increasing for cancer and infectious disease treatment $[70,141,142]$. In current opinion, two approaches are 
considered to develop drug carriers for in vivo drug-delivery system based on cell-derived membrane vesicles which include the following: (1) modification and engineering of natural cell membrane vesicles primed with therapeutic compounds to target certain cell types and (2) using the essential characteristics of membrane vesicles in order to design nanoscaled drug vehicles [141]. Lately, exosomes have gained considerable interests for being used as a vehicle for either cell-derived materials or therapeutic drug-delivery systems. Exosomes are ideal candidates for drug delivery because they are bioavailable vehicles, which are known to be well tolerated, bioactive, specific to their target cells, and resistant to metabolic processes and have the ability to easily penetrate through impermeable biological barriers like blood-brain barrier (BBB). Increased evidence suggested that the natural membrane vesicles have more advantages than the synthetic nanoscaled drug systems due to their natural specificity to their target cells [143], their natural stability in blood, and their ability to tolerate the patient's immune response. However, exosomal purification is difficult because mammalian cells usually release small quantities of exosomes; thus exosome-mimetic nanoscaled vesicles were developed when overproduction is needed [38].

\section{Exosomes as Carrier for Therapeutic Agents}

There are so many approaches that can be used in order to load exosomal carriers with therapeutic agents and all were described in detail by Batrakova et al. [93]. There are advantages and disadvantages for each approach, and also this may be restricted to the type of drug, the targeted disease, and the conditions required for a specific type of exosomal cargo. The first one is ex vitro loading of naïve exosomes that are purified from parental donor cells and then incorporated with a therapeutic agent. The other approach is by loading parental cells with a drug, which is subsequently released in the exosomes. The final approach is by transfecting or infecting donor cells with drug-encoding DNA, which is eventually released in exosomes.

Therefore, exosomes serve as effective vehicles for many molecules that would be otherwise rapidly degraded before approaching their target like drugs, proteins, and microRNA/ silent interfering RNA (siRNA). Alvarez-Erviti et al. have provided the first demonstration of biotechnological exploitation of cell membrane vesicles [29]. The authors showed a successful in vivo delivery with low or no toxicity or immunogenicity of exosomes-mediated siRNA to the mouse brain through injection of targeted exosomes. In order to ensure a successful delivery of the injected exosomes to their target cells in vivo and to avoid the exosomal removal of tissues of drug clearance, a novel targeting strategy was suggested. Therefore, exosomal surface protein lamp2b was used to display a targeting peptide to bind (AchR) receptor present on neurons and the vascular endothelium of the bloodbrain barrier (BBB). The $\mathrm{BBB}$ was the major obstacle in the macromolecular drug delivery to the CNS [144]. On the other hand, artificial cell membrane vesicles mimic is also an alternative approach to obtain membrane vesicles and subsequently provides a controlled and clean drug-delivery system.
Currently, specific lipid and protein compositions are used in liposomal drug formulations to create CMV mimics that have similar properties of the natural ones [145]. Gao et al. have presented a novel strategy to generate neutrophil cell membrane-derived nanovesicles to target inflamed vasculature and significantly reduce acute lung inflammation by using nitrogen cavitation. Nitrogen cavitation was described in this study [148], which is a novel approach to fracture cells with no chemicals or long-term physical stress that could disrupt the biological functions of cellular membrane antigens.

\section{Therapeutic Application}

11.1. As Anticancer Drug Delivery. Recently, in vitro and in vivo experimental findings have shown that extracellular vesicles can be used as vehicles for several therapeutic agents for cancer treatment [147]. Previous clinical studies have been conducted in order to assess the efficacy of dendritic cell-derived exosomes (dexosomes) as cancer vaccines. The authors obtained promising results in phase 1 clinical trial following vaccination of metastatic melanoma patients [28] and in patients with advanced non-small cell lung cancer [29]. In a recent study, the effect of exosome-delivered siRNA on target cancer cells was observed. These experimental findings have shown that exosome-mediated siRNA can induce posttranscriptional gene silencing and apoptotic cell death of targeted cancer cells [30]. Smyth et al. have found that tumor-derived exosomes have been used as an effective vehicle for drug delivery [31]. Moreover, experimental studies have shown that exosomes can be used as carriers for therapeutic agents with low molecular weight $[35,149]$. Other studies have demonstrated that when exosomes or exosome-memetic nanovesicles loaded with various chemotherapeutic agents, Dox or PTX, they were able to target tumor cells in mice and significantly inhibit tumor growth without observing any side effects [38, 150, 151]. Jang et al. [28] have found that both Doxloaded exosomes and Dox-loaded nanovesicles demonstrated similar antitumor activity, but Dox-loaded liposomes were not efficient in diminishing tumor growth. Similarly, mesenchymal stromal cells (MSCs) are an efficient mass producer of exosomes, which makes them ideal for drug delivery [61]. Pascucci et al. [33] have shown that MSCs have the ability to pack and then release drug such as Paclitaxel through their microvesicles, suggesting that MSCs can be used for drugdelivery system development with high specificity and more detail is provided in Table 4 [28-38]. Moreover, there are recently published papers showing and commenting on the ability of exosomes in delivering photodynamic drugs, possibly useful in the therapeutics of tumors.

11.2. Exosome Removal as Cancer Therapy. Cancer cells ubiquitously secret exosomes, which transport oncoproteins and other immune suppressive molecules in order to promote tumorigenesis as well as metastasis. Therefore, several attractive therapeutic strategies have been suggested for targeting their cancer activities. Previous studies have suggested the removal of exosomes from the circulation as a strategy to attenuate the exosomal metastatic effect. Researchers have 


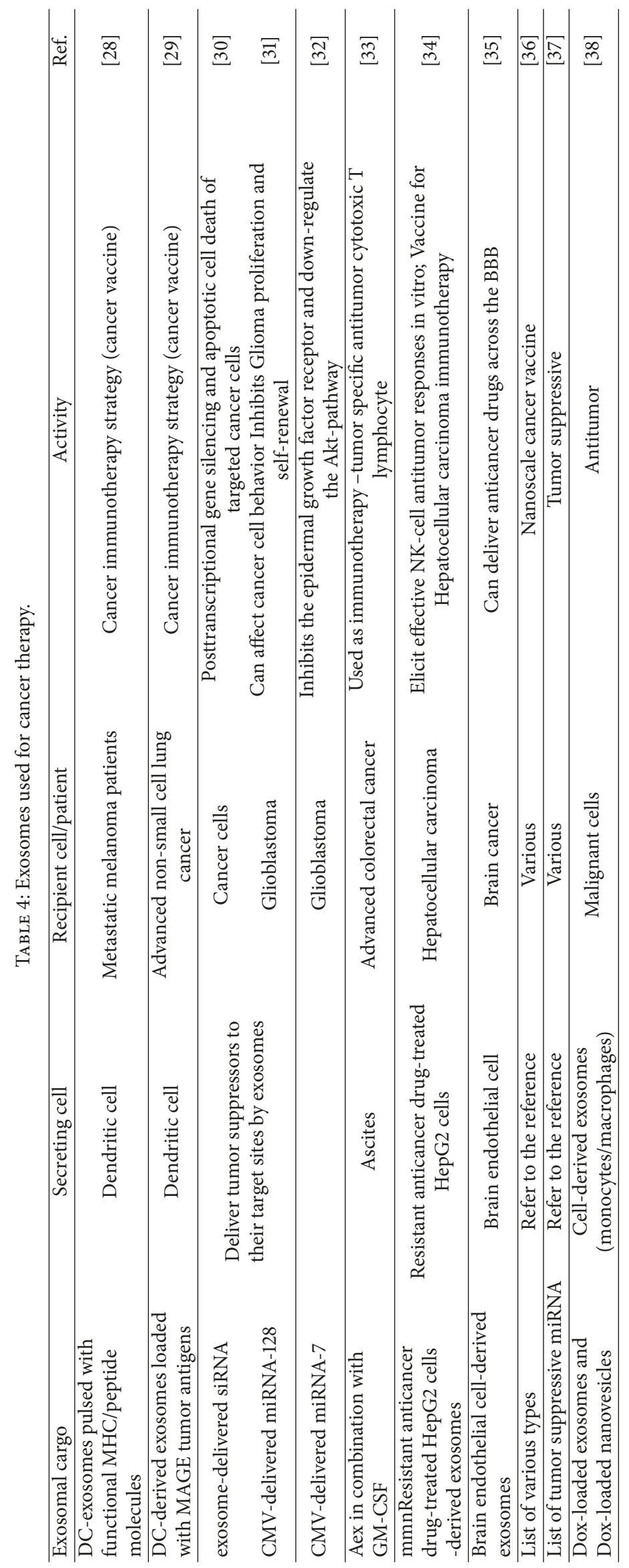


TABLE 5: Novel strategies/devices of exosomal removal for cancer and infectious disease therapy.

\begin{tabular}{lccc}
\hline Mechanism of exosomal removal & Disease & Effect \\
\hline $\begin{array}{l}\text { Extracorporeal hemofiltration of } \\
\text { exosomes }\end{array}$ & Hepatitis C & Minimize viral titers in patients \\
\hline $\begin{array}{l}\text { Exosome enervation by Dimethyl } \\
\text { amiloride (DMA) in mice }\end{array}$ & $\begin{array}{c}\text { Colorectal cancer } \\
\text { [39] }\end{array}$ & $\begin{array}{c}\text { Restore the cyclophosphamide (CTX) } \\
\text { anti-tumor effect through the inhibition of } \\
\text { MDSC functions }\end{array}$ \\
$\begin{array}{l}\text { Extracorporeal filtration of exosomes } \\
\text { The Hemopurifier) }\end{array}$ & $\begin{array}{c}\text { Advanced stage of cancer } \\
\text { patients }\end{array}$ & $\begin{array}{c}\text { To remove exosomes from the blood } \\
\text { [40] }\end{array}$ \\
$\begin{array}{l}\text { Adjunct therapeutic method } \\
\text { HER2osome }\end{array}$ & $\begin{array}{c}\text { Decrease the tumor secreted HER2 } \\
\text { containing exosomes in circulation and } \\
\text { afterward impede HER2 positive breast } \\
\text { cancer progression }\end{array}$ \\
\hline
\end{tabular}

TABLE 6: Exosomes used for infectious diseases treatment.

\begin{tabular}{|c|c|c|c|}
\hline Exosomal cargo & Secreting cell & Biological activity & Ref. \\
\hline $\begin{array}{l}\text { Exosomes pulsed with Toxoplasma } \\
\text { gondii antigens }\end{array}$ & Dendritic cells & $\begin{array}{l}\text { A defensive immune response against } \\
\text { Toxoplasma gondii infection }\end{array}$ & {$[43,44]$} \\
\hline $\begin{array}{l}\text { Exosomes pulsed with Leishmania } \\
\text { major antigens }\end{array}$ & Dendritic cells & $\begin{array}{l}\text { A defensive immune response against } L . \text { major } \\
\text { infection }\end{array}$ & {$[45]$} \\
\hline $\begin{array}{l}\text { Exosomes containing } \mathrm{M} . \\
\text { tuberculosis antigens }\end{array}$ & $\begin{array}{l}\text { Macrophage infected with } \mathrm{M} \text {. } \\
\text { Tuberculosis }\end{array}$ & $\begin{array}{l}\text { Tuberculosis vaccine, activate innate/acquired } \\
\text { immune responses }\end{array}$ & {$[46]$} \\
\hline $\begin{array}{l}\text { shRNA against HCV } \\
\text { replication-loaded exosomes }\end{array}$ & Transfected into several cell types & Decrease in HCV infection of liver cells & {$[47]$} \\
\hline
\end{tabular}

suggested a wide range of methods to inhibit exosome production, which involve targeting microtubules assembly and stability and endosomal-sorting pathway and by using inhibitors of the proton pump $[67,88]$. Marleau et al. have suggested a novel mechanism involving the use of extracorporeal hemofiltration of exosomes from circulation in order to minimize viral titers in patients [157]. Further, more information regarding exosomes removal from cancer and infected cells is listed in Table 5 [39-42].

11.3. Exosomes as Cancer Diagnostic Biomarkers. Depending on the type of tumor and location, exosomes can be isolated from almost all body fluids, including human saliva, serum, breast milk, CSF, urine, and semen [74-77]. Exosomes are novel sources of biomarkers because they contain bioactive molecules, which can help to assess the pathological state of the originated cells [40]. In addition, exosomes can be used to predict or monitor a patient's response to the given treatment. More importantly, exosomes provide noninvasive and continuous access to the required information to be used for tumor progression assessment [40]. It has been documented that the level of exosomes increased in some cancer patients in comparison to healthy individuals and has been correlated with poor prognosis [41]. Recent studies have shown that most of the circulating microRNAs detectable serum and saliva are concentrated in tumor-derived exosomes [152]. Extensive studies have shown that tumor-derived exosomes from either tumor cells or extracellular fluids of cancer patients can be used as biomarkers because they have a unique molecular signature on their biocontents (proteins, DNA/RNA molecules) [153-155]. A list of exosomes isolated from biofluids of cancer patients used as biomarkers were prepared with details in previous studies $[33,40]$.

\section{Exosomes Used for Infectious Disease Treatment}

Bukong et al. have provided a novel mechanistic strategy for HCV transmission that can compromise immune-based therapies for $\mathrm{HCV}$ infection and thus suggested potential therapeutic strategies in order to block exosome-mediated transmission of HCV infection [132]. The clinical application of extracellular vesicles is discussed in detail: (i) therapeutic application and both (ii) diagnosis and therapy together [156]. Exosomes are recognized as a novel therapeutic tool for antitumor therapy, immune-modulation regenerative therapy, pathogen vaccination, and drug delivery but there is still a need for high level cooperation between researchers and expert clinicians for approval from recognized authorities [157]. Table 6 illustrates a number of studies that provided evidence for exosomes used for infectious disease treatment [43-47].

\section{Benefits and Future Prospects}

Exosomes are cell-derived membrane vesicles secreted by different cell types and present in body fluids. Proteomic profiling of EVs demonstrated that these vesicles play a valuable role in cellular communications and they act as natural vehicles for cell signaling proteins and genetic molecules. These findings indicated that it is possible to explore the vesicles as novel drug-delivery systems for many therapeutic agents that targeted different diseases such as cancers, infectious 
diseases, and cardiovascular disease. European Cooperation in Science and Technology and International Society for Extracellular Vesicles (ISEV) are also constructing a network on Microvesicles and Exosomes in Health and Disease (ME$\mathrm{HaD}$ ) for ensuring the safety aspect and future application of exosomes in drugs.

In some cases exosomes not only are an ideal vehicle for therapeutic agents but also have been used as diagnostic and prognostic indicators for various cancers. Further studies of exosomes in the pathogenesis of cancer will open new avenues to explore novel diagnostic and therapeutic strategies. Isolation of vesicles of specific size and properties from the bacterial cells and application in drug delivery will be most fascinating research area in future because they will be cheaper and safe from cancers cell exosomes. Yield optimization and purification still require a single technique which is not available, and hopefully in future research will help in developing a single step device for development, purification, and characterization. Furthermore, the findings discussed in this review demonstrated that membrane-derived vesicles play a valuable role in infection biology. This applies to all organisms with different range of complexity from prions to eukaryotic pathogens. Further studies are needed to investigate more pathogens-derived exosomes that play a role in infection transmission and pathogenesis and to explore other novel therapeutic strategies to block exosome-mediated infection transmission. Further studies are also needed to explore novel bacterial species that are able to secrete outer membrane vesicles during their normal growth. More investigations are also needed to study the biogenesis of membrane vesicles in Gram-negative bacteria, which will help to generate more ideal outer membrane vesicles and improve human health. It is also important to study the mechanism of outer membrane vesiculation and to identify the essential envelop compositions that may play a role in vesicles generation. Therefore, a novel antibiotic could be designed to target these virulence components, which will help to inhibit bacterial growth and pathogens.

Novel insights for exosome-mediated drug-delivery systems were illustrated, which is important for the development of novel therapeutics and vaccines. In addition, there is an urgent need to develop advanced technologies to generate more controllable and homogenous membrane vesicles to be used for drug development. Finally, the findings discussed in this article showed the therapeutic effects of exosomes when loaded with drugs for the targeted diseases. The newly discovered drug-loaded exosomes should go for further animal testing and clinical trials to make the formulations ready in the market for clinical applications and to improve the therapeutic index of established drugs.

\section{Conclusion}

Taken together, these findings have shown that there is a relation between exosomes and cancer or infection biology, which is important for the development of novel therapeutics and vaccines. Exosomes are ideal candidates for drug delivery and further studies are needed to explore novel strategies of exosome-mediated therapies particularly for cancer and infectious diseases. We have also discussed the major obstacles of exosome-mediated drug development and the most common methods used for exosomes generation and purification. We also confer the need for developing advanced technologies to generate more ideal and controllable exosomes for drug-delivery systems.

\section{Conflicts of Interest}

The authors declare that they have no conflicts of interest.

\section{Acknowledgments}

This research was financially supported by the Center of Excellence in Environmental Studies (CEES) and Ministry of Higher Education of Saudi Arabia.

\section{References}

[1] M. P. Zaborowski, L. Balaj, X. O. Breakefield, and C. P. Lai, "Extracellular vesicles: composition, biological relevance, and methods of study," Bioscience, vol. 65, no. 8, pp. 783-797, 2015.

[2] J. De Toro, L. Herschlik, C. Waldner, and C. Mongini, "Emerging roles of exosomes in normal and pathological conditions: new insights for diagnosis and therapeutic applications," Frontiers in Immunology, vol. 6, article 203, 2015.

[3] K. I. Willig, S. O. Rizzoli, V. Westphal, R. Jahn, and S. W. Hell, "STED microscopy reveals that synaptotagmin remains clustered after synaptic vesicle exocytosis," Nature, vol. 440, no. 7086, pp. 935-939, 2006.

[4] M. Bates, B. Huang, G. T. Dempsey, and X. Zhuang, "Multicolor super-resolution imaging with photo-switchable fluorescent probes," Science, vol. 317, no. 5845, pp. 1749-1753, 2007.

[5] S. A. Soper and A. Rasooly, "Cancer: A global concern that demands new detection technologies," Analyst, vol. 141, no. 2, pp. 367-370, 2016.

[6] I. Parolini, C. Federici, C. Raggi et al., "Microenvironmental pH is a key factor for exosome traffic in tumor cells," The Journal of Biological Chemistry, vol. 284, no. 49, pp. 34211-34222, 2009.

[7] C. Beyer and D. S. Pisetsky, "The role of microparticles in the pathogenesis of rheumatic diseases," Nature Reviews Rheumatology, vol. 6, no. 1, pp. 21-29, 2010.

[8] M. A. Livshts, E. Khomyakova, E. G. Evtushenko et al., "Isolation of exosomes by differential centrifugation: Theoretical analysis of a commonly used protocol," Scientific Reports, vol. 5, Article ID 17319, 2015.

[9] D. W. Greening, R. Xu, H. Ji, B. J. Tauro, and R. J. Simpson, “A protocol for exosome isolation and characterization: Evaluation of ultracentrifugation, density-gradient separation, and immunoaffinity capture methods," Methods in Molecular Biology, vol. 1295, pp. 179-209, 2015.

[10] A. N. Böing, E. van der Pol, A. E. Grootemaat, F. A. W. Coumans, A. Sturk, and R. Nieuwland, "Single-step isolation of extracellular vesicles by size-exclusion chromatography," Journal of Extracellular Vesicles (JEV), vol. 3, no. 1, Article ID 23430, 2014.

[11] R. Grant, E. Ansa-Addo, D. Stratton et al., "A filtration-based protocol to isolate human Plasma Membrane-derived Vesicles and exosomes from blood plasma," Journal of Immunological Methods, vol. 371, no. 1-2, pp. 143-151, 2011. 
[12] D. D. Taylor and S. Shah, "Methods of isolating extracellular vesicles impact down-stream analyses of their cargoes," Methods, vol. 87, pp. 3-10, 2015.

[13] M. F. Peterson, N. Otoc, J. K. Sethi, A. Gupta, and T. J. Antes, "Integrated systems for exosome investigation," Methods, vol. 87, pp. 31-45, 2015.

[14] E. Van der Pol, F. A. W. Coumans, A. E. Grootemaat et al., "Particle size distribution of exosomes and microvesicles determined by transmission electron microscopy, flow cytometry, nanoparticle tracking analysis, and resistive pulse sensing," Journal of Thrombosis and Haemostasis, vol. 12, no. 7, pp. 1182-1192, 2014.

[15] G. Vogel, A. Strauss, B. Jenni et al., "Development and validation of a protocol for cell line identification by MALDI-TOF MS," BMC Proceedings, vol. 5, no. Suppl 8, p. P45, 2011.

[16] M. A. Obeid, I. Khadra, A. B. Mullen, R. J. Tate, and V. A. Ferro, "The effects of hydration media on the characteristics of nonionic surfactant vesicles (NISV) prepared by microfluidics," International Journal of Pharmaceutics, vol. 516, no. 1-2, pp. 5260, 2017.

[17] G. Di Noto, A. Bugatti, A. Zendrini et al., "Merging colloidal nanoplasmonics and surface plasmon resonance spectroscopy for enhanced profiling of multiple myeloma-derived exosomes," Biosensors and Bioelectronics, vol. 77, pp. 518-524, 2016.

[18] M. He, J. Crow, M. Roth, Y. Zeng, and A. K. Godwin, "Integrated immunoisolation and protein analysis of circulating exosomes using microfluidic technology," Lab on a Chip , vol. 14, no. 19, pp. 3773-3780, 2014.

[19] A. A. I. Sina, R. Vaidyanathan, S. Dey, L. G. Carrascosa, M. J. A. Shiddiky, and M. Trau, "Real time and label free profiling of clinically relevant exosomes," Scientific Reports, vol. 6, Article ID 30460, 2016.

[20] E. Foglio, G. Puddighinu, P. Fasanaro et al., "Exosomal clusterin, identified in the pericardial fluid, improves myocardial performance following MI through epicardial activation, enhanced arteriogenesis and reduced apoptosis," International Journal of Cardiology, vol. 197, Article ID 20664, pp. 333-347, 2015.

[21] J. M. Silverman, J. Clos, C. C. De'Oliveira et al., "An exosomebased secretion pathway is responsible for protein export from Leishmania and communication with macrophages," Journal of Cell Science, vol. 123, no. 6, pp. 842-852, 2010.

[22] D. G. Nguyen, A. Booth, S. J. Gould, and J. E. K. Hildreth, "Evidence that HIV budding in primary macrophages occurs through the exosome release pathway," The Journal of Biological Chemistry, vol. 278, no. 52, pp. 52347-52354, 2003.

[23] S. Bhatnagar and J. S. Schorey, "Exosomes released from infected macrophages contain Mycobacterium avium glycopeptidolipids and are proinflammatory," The Journal of Biological Chemistry, vol. 282, no. 35, pp. 25779-25789, 2007.

[24] J. H. Campos, R. P. Soares, K. Ribeiro, A. Cronemberger Andrade, W. L. Batista, and A. C. Torrecilhas, "Extracellular Vesicles: Role in Inflammatory Responses and Potential Uses in Vaccination in Cancer and Infectious Diseases," Journal of Immunology Research, vol. 2015, Article ID 832057, 2015.

[25] J. M. Silverman and N. E. Reiner, "Exosomes and other microvesicles in infection biology: organelles with unanticipated phenotypes," Cellular Microbiology, vol. 13, no. 1, pp. 1-9, 2011.

[26] M. Lenassi, G. Cagney, M. Liao et al., "HIV Nef is secreted in exosomes and triggers apoptosis in bystander $\mathrm{CD}^{+} \mathrm{T}$ cells," Traffic, vol. 11, no. 1, pp. 110-122, 2010.
[27] B. Fevrier, D. Vilette, F. Archer et al., "Cells release prions in association with exosomes," Proceedings of the National Acadamy of Sciences of the United States of America, vol. 101, no. 26, pp. 9683-9688, 2004.

[28] S. C. Jang, O. Y. Kim, C. M. Yoon et al., "Bioinspired exosomemimetic nanovesicles for targeted delivery of chemotherapeutics to malignant tumors," ACS Nano, vol. 7, no. 9, pp. 7698-7710, 2013.

[29] L. Alvarez-Erviti, Y. Seow, H. Yin, C. Betts, S. Lakhal, and M. J. A. Wood, "Delivery of siRNA to the mouse brain by systemic injection of targeted exosomes," Nature Biotechnology, vol. 29, no. 4, pp. 341-345, 2011.

[30] M. Çağdaş, A. D. Sezer, and S. Bucak, "Liposomes as potential drug carrier systems for drug delivery," Application of Nanotechnology in Drug Delivery, 2014.

[31] T. Smyth, M. Kullberg, N. Malik, P. Smith-Jones, M. W. Graner, and T. J. Anchordoquy, "Biodistribution and delivery efficiency of unmodified tumor-derived exosomes," Journal of Controlled Release, vol. 199, pp. 145-155, 2015.

[32] T. Yang, P. Martin, B. Fogarty et al., "Exosome delivered anticancer drugs across the blood-brain barrier for brain cancer therapy in Danio Rerio," Pharmaceutical Research, vol. 32, no. 6, pp. 2003-2014, 2015.

[33] L. Pascucci, V. Coccè, A. Bonomi et al., "Paclitaxel is incorporated by mesenchymal stromal cells and released in exosomes that inhibit in vitro tumor growth: a new approach for drug delivery," Journal of Controlled Release, vol. 192, pp. 262-270, 2014.

[34] Y. Tian, S. Li, J. Song et al., "A doxorubicin delivery platform using engineered natural membrane vesicle exosomes for targeted tumor therapy," Biomaterials, vol. 35, no. 7, pp. 2383-2390, 2014.

[35] K. B. Johnsen, J. M. Gudbergsson, M. N. Skov, L. Pilgaard, T. Moos, and M. Duroux, "A comprehensive overview of exosomes as drug delivery vehicles-endogenous nanocarriers for targeted cancer therapy," Biochimica et Biophysica Acta (BBA) - Reviews on Cancer, vol. 1846, no. 1, pp. 75-87, 2014.

[36] S. Rani, A. E. Ryan, M. D. Griffin, and T. Ritter, "Mesenchymal stem cell-derived extracellular vesicles: toward cell-free therapeutic applications," Molecular Therapy, vol. 23, no. 5, pp. 812823, 2015.

[37] J. Godlewski, M. O. Nowicki, A. Bronisz et al., "Targeting of the Bmi-1 oncogene/stem cell renewal factor by MicroRNA-128 inhibits glioma proliferation and self-renewal," Cancer Research, vol. 68, no. 22, pp. 9125-9130, 2008.

[38] H. Gankema, J. Wensink, P. A. M. Guinee, W. H. Jansen, and B. Witholt, "Some characteristics of the outer membrane material released by growing enterotoxigenic Escherichia coli," Infection and Immunity, vol. 29, no. 2, pp. 704-713, 1980.

[39] B. Kefas, J. Godlewski, L. Comeau et al., "microRNA-7 inhibits the epidermal growth factor receptor and the akt pathway and is down-regulated in glioblastoma," Cancer Research, vol. 68, no. 10, pp. 3566-3572, 2008.

[40] S. Dai, D. Wei, Z. Wu et al., "Phase I clinical trial of autologous ascites-derived exosomes combined with GM-CSF for colorectal cancer," Molecular Therapy, vol. 16, no. 4, pp. 782-790, 2008.

[41] L.-H. Lv, Y.-L. Wan, Y. Lin et al., "Anticancer drugs cause release of exosomes with heat shock proteins from human hepatocellular carcinoma cells that elicit effective natural killer cell antitumor responses in vitro," The Journal of Biological Chemistry, vol. 287, no. 19, pp. 15874-15885, 2012. 
[42] X. Zhang, X. Yuan, H. Shi, L. Wu, H. Qian, and W. Xu, "Exosomes in cancer: Small particle, big player," Journal of Hematology \& Oncology, vol. 8, no. 1, article no. 83, 2015.

[43] F. Chalmin, S. Ladoire, G. Mignot et al., "Membrane-associated Hsp72 from tumor-derived exosomes mediates STAT3-dependent immunosuppressive function of mouse and human myeloid-derived suppressor cells," The Journal of Clinical Investigation, vol. 120, no. 2, pp. 457-471, 2010.

[44] F. Hochberg and et al., "Second International Meeting of ISEV 2013: Boston, USA, April 17th-20th," Journal of Extracellular Vesicles, 2013.

[45] J. Rak, "Extracellular vesicles-biomarkers and effectors of the cellular interactome in cancer," Frontiers in Pharmacology, vol. 4, article 21, 2013.

[46] H. K. Kim, K. S. Song, Y. S. Park et al., "Elevated levels of circulating platelet microparticles, VEGF, IL-6 and RANTES in patients with gastric cancer: possible role of a metastasis predictor," European Journal of Cancer, vol. 39, no. 2, pp. 184-191, 2003.

[47] A. Gallo, M. Tandon, I. Alevizos, and G. G. Illei, “The majority of microRNAs detectable in serum and saliva is concentrated in exosomes," PLoS ONE, vol. 7, no. 3, Article ID e30679, 2012.

[48] L. A. Emery, A. Tripathi, C. King et al., "Early dysregulation of cell adhesion and extracellular matrix pathways in breast cancer progression," The American Journal of Pathology, vol. 175, no. 3, pp. 1292-1302, 2009.

[49] J. S. Schorey, Y. Cheng, P. P. Singh, and V. L. Smith, "Exosomes and other extracellular vesicles in host-pathogen interactions," EMBO Reports, vol. 16, pp. 24-43, 2015.

[50] A. Shimoda, K. Ueda, S. Nishiumi et al., "Exosomes as nanocarriers for systemic delivery of the Helicobacter pylori virulence factor CagA," Scientific Reports, vol. 6, Article ID 18346, 2016.

[51] M. Logozzi, A. de Milito, L. Lugini et al., "High levels of exosomes expressing CD63 and caveolin-1 in plasma of melanoma patients," PLoS ONE, vol. 4, no. 4, Article ID e5219, 2009.

[52] J. VanDeun, A. Hendrix, and On behalf of the EV-TRACK consortium, "Is your article EV-TRACKed?" Journal of Extracellular Vesicles, vol. 6, no. 1, Article ID 1379835, 2017.

[53] P. Wolf, "The nature and significance of platelet products in human plasma.," British Journal of Haematology, vol. 13, no. 3, pp. 269-288, 1967.

[54] E. G. Trams, C. J. Lauter, J. Norman Salem, and U. Heine, "Exfoliation of membrane ecto-enzymes in the form of microvesicles," Biochimica et Biophysica Acta, vol. 645, no. 1, pp. 6370, 1981.

[55] R. M. Johnstone, M. Adam, J. R. Hammond, L. Orr, and C. Turbide, "Vesicle formation during reticulocyte maturation. Association of plasma membrane activities with released vesicles (exosomes)," The Journal of Biological Chemistry, vol. 262, no. 19, pp. 9412-9420, 1987.

[56] F. Doonan and T. G. Cotter, "Morphological assessment of apoptosis," Methods, vol. 44, no. 3, pp. 200-204, 2008.

[57] M. Schiller, I. Bekeredjian-Ding, P. Heyder, N. Blank, A. D. Ho, and H.-M. Lorenz, "Autoantigens are translocated into small apoptotic bodies during early stages of apoptosis," Cell Death \& Differentiation, vol. 15, no. 1, pp. 183-191, 2008.

[58] S. A. A. Kooijmans, P. Vader, S. M. van Dommelen, W. W. van Solinge, and R. M. Schiffelers, "Exosome mimetics: a novel class of drug delivery systems," International Journal of Nanomedicine, vol. 7, pp. 1525-1541, 2012.
[59] D. Mayrand and D. Grenier, "Biological activities of outer membrane vesicles," Canadian Journal of Microbiology, vol. 35, no. 6, pp. 607-613, 1989.

[60] A. Kulp and M. J. Kuehn, "Biological Functions and biogenesis of secreted bacterial outer membrane vesicles," Annual Review of Microbiology, vol. 64, pp. 163-184, 2010.

[61] D. Hoekstra, J. W. van der Laan, L. de Leij, and B. Witholt, "Release of outer membrane fragments from normally growing Escherichia coli," BBA - Biomembranes, vol. 455, no. 3, pp. 889899, 1976.

[62] I. W. Devoe and J. E. Gilchrist, "Release of endotoxin in the form of cell wall blebs during in vitro growth of Neisseria meningitidis," The Journal of Experimental Medicine, vol. 138, no. 5, pp. 1156-1167, 1973.

[63] J. L. Kadurugamuwa and T. J. Beveridge, "Virulence factors are released from Pseudomonas aeruginosa in association with membrane vesicles during normal growth and exposure to gentamicin: a novel mechanism of enzyme secretion," Journal of Bacteriology, vol. 177, no. 14, pp. 3998-4008, 1995.

[64] R. Fiocca, V. Necchi, P. Sommi et al., "Release of Helicobacter pylori vacuolating cytotoxin by both a specific secretion pathway and budding of outer membrane vesicles. Uptake of released toxin and vesicles by gastric epithelium," The Journal of Pathology, vol. 188, no. 2, pp. 220-226, 1999.

[65] M. L. Rodrigues, E. S. Nakayasu, I. C. Almeida, and L. Nimrichter, "The impact of proteomics on the understanding of functions and biogenesis of fungal extracellular vesicles," Journal of Proteomics, vol. 97, pp. 177-186, 2014.

[66] S. Bhatnagar, K. Shinagawa, F. J. Castellino, and J. S. Schorey, "Exosomes released from macrophages infected with intracellular pathogens stimulate a proinflammatory response in vitro and in vivo," Blood, vol. 110, no. 9, pp. 3234-3244, 2007.

[67] C. Théry, S. Amigorena, G. Raposo, and A. Clayton, "Isolation and characterization of exosomes from cell culture supernatants and biological fluids," Current Protocols in Cell Biology, vol. 3, 2006.

[68] E. N. M. Nolte, S. I. Buschow, S. M. Anderton, W. Stoorvogel, and M. H. M. Wauben, "Activated T cells recruit exosomes secreted by dendritic cells via LFA-1," Blood, vol. 113, no. 9, pp. 1977-1981, 2009.

[69] A. Clayton, A. Turkes, H. Navabi, M. D. Mason, and Z. Tabi, "Induction of heat shock proteins in B-cell exosomes," Journal of Cell Science, vol. 118, no. 16, pp. 3631-3638, 2005.

[70] R. W. Y. Yeo, R. C. Lai, B. Zhang et al., "Mesenchymal stem cell: an efficient mass producer of exosomes for drug delivery," $A d$ vanced Drug Delivery Reviews, vol. 65, no. 3, pp. 336-341, 2013.

[71] G. Skogberg, V. Lundberg, M. Berglund et al., "Human thymic epithelial primary cells produce exosomes carrying tissuerestricted antigens," Immunology \& Cell Biology, vol. 93, no. 8, pp. 727-734, 2015.

[72] J. Song, X. Chen, M. Wang, Y. Xing, Z. Zheng, and S. Hu, "Cardiac endothelial cell-derived exosomes induce specific regulatory B cells," Scientific Reports, vol. 4, article 7583, 2014.

[73] X. Li, Z. Zhang, T. Beiter, and H. J. Schluesener, "Nanovesicular vaccines: Exosomes," Archivum Immunologiae et Therapia Experimentalis, vol. 53, no. 4, pp. 329-335, 2005.

[74] C. Lässer, V. S. Alikhani, K. Ekström et al., "Human saliva, plasma and breast milk exosomes contain RNA: uptake by macrophages," Journal of Translational Medicine, vol. 9, article 9, 2011. 
[75] J. M. Street, P. E. Barran, C. L. Mackay et al., "Identification and proteomic profiling of exosomes in human cerebrospinal fluid," Journal of Translational Medicine, vol. 10, no. 1, article 5, 2012.

[76] J. W. Dear, J. M. Street, and M. A. Bailey, "Urinary exosomes: a reservoir for biomarker discovery and potential mediators of intrarenal signalling," Proteomics, vol. 13, no. 10-11, pp. 15721580, 2013.

[77] M. N. Madison, R. J. Roller, and C. M. Okeoma, "Human semen contains exosomes with potent anti-HIV-1 activity," Retrovirology, vol. 11, article 102, 2014.

[78] H. Im, H. Shao, Y. I. Park et al., "Label-free detection and molecular profiling of exosomes with a nano-plasmonic sensor," Nature Biotechnology, vol. 32, no. 5, pp. 490-495, 2014.

[79] J. Lötvall, A. F. Hill, F. Hochberg et al., "Minimal experimental requirements for definition of extracellular vesicles and their functions: a position statement from the International Society for Extracellular Vesicles," Journal of Extracellular Vesicles (JEV), vol. 3, Article ID 26913, 2014.

[80] C. Théry, M. Ostrowski, and E. Segura, "Membrane vesicles as conveyors of immune responses," Nature Reviews Immunology, vol. 9, no. 8, pp. 581-593, 2009.

[81] S. Mathivanan, J. W. E. Lim, B. J. Tauro, H. Ji, R. L. Moritz, and R. J. Simpson, "Proteomics analysis of A33 immunoaffinitypurified exosomes released from the human colon tumor cell line LIM1215 reveals a tissue-specific protein signature," Molecular \& Cellular Proteomics, vol. 9, no. 2, pp. 197-208, 2010.

[82] E. Work, K. W. Knox, and M. Vesk, "The chemistry and electron microscopy of an extracellular lipopolysaccharide from escherichia coli," Annals of the New York Academy of Sciences, vol. 133, no. 2, pp. 438-449, 1966.

[83] L. Zhou, R. Srisatjaluk, D. E. Justus, and R. J. Doyle, "On the origin of membrane vesicles in Gram-negative bacteria," FEMS Microbiology Letters, vol. 163, no. 2, pp. 223-228, 1998.

[84] C. Schwechheimer, C. J. Sullivan, and M. J. Kuehn, "Envelope control of outer membrane vesicle production in Gram-negative bacteria," Biochemistry, vol. 52, no. 18, pp. 3031-3040, 2013.

[85] J. Wensink and B. Witholt, "Outer-Membrane Vesicles Released by Normally Growing Escherichia coli Contain Very Little Lipoprotein," European Journal of Biochemistry, vol. 116, no. 2, pp. 331-335, 1981.

[86] C. Théry, L. Zitvogel, and S. Amigorena, "Exosomes: composition, biogenesis and function," Nature Reviews Immunology, vol. 2, no. 8, pp. 569-579, 2002.

[87] K. Trajkovic, C. Hsu, S. Chiantia et al., "Ceramide triggers budding of exosome vesicles into multivesicular endosomes," Science, vol. 319, no. 5867, pp. 1244-1247, 2008.

[88] M. Ostrowski, N. B. Carmo, S. Krumeich et al., "Rab27a and Rab27b control different steps of the exosome secretion pathway," Nature Cell Biology, vol. 12, no. 1, pp. 19-30, 2010.

[89] A. Savina, C. M. Fader, M. T. Damiani, and M. I. Colombo, "Rabl1 promotes docking and fusion of multivesicular bodies in a calcium-dependent manner," Traffic, vol. 6, no. 2, pp. 131-143, 2005.

[90] F. Cappello, M. Logozzi, C. Campanella et al., "Exosome levels in human body fluids: A tumor marker by themselves?” European Journal of Pharmaceutical Sciences, vol. 96, pp. 93-98, 2017.

[91] A. Liga, A. D. B. Vliegenthart, W. Oosthuyzen, J. W. Dear, and M. Kersaudy-Kerhoas, "Exosome isolation: A microfluidic roadmap," Lab on a Chip, vol. 15, no. 11, pp. 2388-2394, 2015.
[92] B. J. Tauro, D. W. Greening, R. A. Mathias et al., "Comparison of ultracentrifugation, density gradient separation, and immunoaffinity capture methods for isolating human colon cancer cell line LIM1863-derived exosomes," Methods, vol. 56, no. 2, pp. 293-304, 2012.

[93] E. V. Batrakova and M. S. Kim, "Using exosomes, naturallyequipped nanocarriers, for drug delivery," Journal of Controlled Release, vol. 219, pp. 396-405, 2015.

[94] H. Kalra, C. G. Adda, M. Liem et al., "Comparative proteomics evaluation of plasma exosome isolation techniques and assessment of the stability of exosomes in normal human blood plasma," Proteomics, vol. 13, no. 22, pp. 3354-3364, 2013.

[95] L. Muller, C.-S. Hong, D. B. Stolz, S. C. Watkins, and T. L. Whiteside, "Isolation of biologically-active exosomes from human plasma," Journal of Immunological Methods, vol. 411, pp. $55-65,2014$.

[96] J. Van Deun, P. Mestdagh, R. Sormunen et al., “The impact of disparate isolation methods for extracellular vesicles on downstream RNA profiling," Journal of Extracellular Vesicles (JEV), vol. 3, no. 1, Article ID 24858, 2014.

[97] H. Saari, E. Lázaro-Ibáñez, T. Viitala, E. Vuorimaa-Laukkanen, P. Siljander, and M. Yliperttula, "Microvesicle- and exosomemediated drug delivery enhances the cytotoxicity of Paclitaxel in autologous prostate cancer cells," Journal of Controlled Release, vol. 220, pp. 727-737, 2015.

[98] R. A. Dragovic, C. Gardiner, A. S. Brooks et al., "Sizing and phenotyping of cellular vesicles using nanoparticle tracking analysis," Nanomedicine: Nanotechnology, Biology and Medicine, vol. 7, no. 6, pp. 780-788, 2011.

[99] G. Cesi, G. Walbrecq, C. Margue, and S. Kreis, "Transferring intercellular signals and traits between cancer cells: extracellular vesicles as 'homing pigeons,' Cell Communication and Signaling, vol. 14, no. 1, article 13, 2016.

[100] Y.-G. Zhou, R. M. Mohamadi, M. Poudineh et al., "Interrogating Circulating Microsomes and Exosomes Using Metal Nanoparticles," Small, vol. 12, no. 6, pp. 727-732, 2016.

[101] E. Helmerhorst, D. J. Chandler, M. Nussio, and C. D. Mamotte, "Real-time and label-free bio-sensing of molecular interactions by surface plasmon resonance: A laboratory medicine perspective," The Clinical Biochemist Reviews, vol. 33, no. 4, pp. 161-173, 2012.

[102] D. L. M. Rupert, G. V. Shelke, G. Emilsson et al., "Dual-Wavelength Surface Plasmon Resonance for Determining the Size and Concentration of Sub-Populations of Extracellular Vesicles," Analytical Chemistry, vol. 88, no. 20, pp. 9980-9988, 2016.

[103] L. Grasso, R. Wyss, L. Weidenauer et al., "Molecular screening of cancer-derived exosomes by surface plasmon resonance spectroscopy," Analytical and Bioanalytical Chemistry, vol. 407, no. 18, article no. 8711, pp. 5425-5432, 2015.

[104] R. Wyss, L. Grasso, C. Wolf, W. Grosse, D. Demurtas, and H. Vogel, "Molecular and dimensional profiling of highly purified extracellular vesicles by fluorescence fluctuation spectroscopy," Analytical Chemistry, vol. 86, no. 15, pp. 7229-7233, 2014.

[105] L. Zhu, K. Wang, J. Cui et al., "Label-free quantitative detection of tumor-derived exosomes through surface plasmon resonance imaging," Analytical Chemistry, vol. 86, no. 17, pp. 8857-8864, 2014.

[106] D. M. B. Post, D. Zhang, J. S. Eastvold, A. Teghanemt, B. W. Gibson, and J. P. Weiss, "Biochemical and functional characterization of membrane blebs purified from Neisseria meningitidis 
serogroup B," The Journal of Biological Chemistry, vol. 280, no. 46, pp. 38383-38394, 2005.

[107] S. J. Bauman and M. J. Kuehn, "Purification of outer membrane vesicles from Pseudomonas aeruginosa and their activation of an IL-8 response," Microbes and Infection, vol. 8, no. 9-10, pp. 2400-2408, 2006.

[108] M. Nevot, V. Deroncelé, P. Messner, J. Guinea, and E. Mercadé, "Characterization of outer membrane vesicles released by the psychrotolerant bacterium Pseudoalteromonas antarctica NF3," Environmental Microbiology, vol. 8, no. 9, pp. 1523-1533, 2006.

[109] E.-Y. Lee, Y. B. Joo, W. P. Gun et al., "Global proteomic profiling of native outer membrane vesicles derived from Escherichia coli," Proteomics, vol. 7, no. 17, pp. 3143-3153, 2007.

[110] U. K. Laemmli, "Cleavage of structural proteins during the assembly of the head of bacteriophage T4," Nature, vol. 227, no. 5259, pp. 680-685, 1970.

[111] J. Sambrook, E. F. Fritsch, and T. Maniatis, Molecular cloning: A laboratory manual, 2an edition, 1983.

[112] J. A. Tickner, A. J. Urquhart, S. A. Stephenson, D. J. Richard, and K. J. O’Byrne, "Functions and therapeutic roles of exosomes in cancer," Frontiers in Oncology, vol. 4, article 127, 2014.

[113] S. Khan, J. R. Aspe, M. G. Asumen et al., "Extracellular, cell-permeable survivin inhibits apoptosis while promoting proliferative and metastatic potential," British Journal of Cancer, vol. 100, no. 7, pp. 1073-1086, 2009.

[114] Z. Y. A. Elmageed, Y. Yang, R. Thomas et al., "Neoplastic reprogramming of patient-derived adipose stem cells by prostate cancer cell-associated exosomes," Stem Cells, vol. 32, no. 4, pp. 983-997, 2014.

[115] C. Cossetti, L. Lugini, L. Astrologo, I. Saggio, S. Fais, and C. Spadafora, "Soma-to-germline transmission of RNA in mice xenografted with human tumour cells: possible transport by exosomes," PLoS ONE, vol. 9, no. 7, Article ID e101629, 2014.

[116] L. Lugini, M. Valtieri, C. Federici et al., "Exosomes from human colorectal cancer induce a tumor-like behavior in colonic mesenchymal stromal cells," Oncotarget, vol. 7, no. 31, pp. 5008650098, 2016.

[117] J. E. Park, H. S. Tan, A. Datta et al., "Hypoxic tumor cell modulates its microenvironment to enhance angiogenic and metastatic potential by secretion of proteins and exosomes," Molecular \& Cellular Proteomics, vol. 9, no. 6, pp. 1085-1099, 2010.

[118] M. Aga, G. L. Bentz, S. Raffa et al., "Exosomal HIF1 $\alpha$ supports invasive potential of nasopharyngeal carcinoma-associated LMP1-positive exosomes," Oncogene, vol. 33, no. 37, pp. 46134622, 2014.

[119] H. Peinado, M. Alečković, S. Lavotshkin et al., "Melanoma exosomes educate bone marrow progenitor cells toward a prometastatic phenotype through MET," Nature Medicine, vol. 18, no. 6, pp. 883-891, 2012.

[120] A. Zomer, C. Maynard, F. J. Verweij et al., "In vivo imaging reveals extracellular vesicle-mediated phenocopying of metastatic behavior," Cell, vol. 161, no. 5, pp. 1046-1057, 2015.

[121] Y. Wei, X. Lai, S. Yu et al., "Exosomal miR-221/222 enhances tamoxifen resistance in recipient ER-positive breast cancer cells," Breast Cancer Research and Treatment, vol. 147, no. 2, pp. 423-431, 2014.

[122] R. Safaei, B. J. Larson, T. C. Cheng et al., "Abnormal lysosomal trafficking and enhanced exosomal export of cisplatin in drugresistant human ovarian carcinoma cells," Molecular Cancer Therapeutics, vol. 4, no. 10, pp. 1595-1604, 2005.
[123] C. Federici, F. Petrucci, S. Caimi et al., "Exosome release and low $\mathrm{pH}$ belong to a framework of resistance of human melanoma cells to cisplatin," PLoS ONE, vol. 9, no. 2, Article ID e88193, 2014.

[124] C. Gutiérrez-Vázquez, C. Villarroya-Beltri, M. Mittelbrunn, and F. Sánchez-Madrid, "Transfer of extracellular vesicles during immune cell-cell interactions," Immunological Reviews, vol. 251, no. 1, pp. 125-142, 2013.

[125] G. Andreola, L. Rivoltini, C. Castelli et al., "Induction of lymphocyte apoptosis by tumor cell secretion of FasL-bearing microvesicles," The Journal of Experimental Medicine, vol. 195, no. 10, pp. 1303-1316, 2002.

[126] V. G. Y. Nanda, W. Peng, P. Hwu et al., "Melanoma and immunotherapy bridge 2015," Journal of Translational Medicine, vol. 14, supplement 1, p. 65, 2015.

[127] "Scientific Program 2012 ISEV meeting Wednesday 18th April," Journal of Extracellular Vesicles (JEV), vol. 1, no. 1, p. 18182, 2012.

[128] M. M. Rashid, A. Runci, L. Polletta et al., "Muscle LIM protein/ CSRP3: a mechanosensor with a role in autophagy," Cell Death Discovery, vol. 1, no. 1, 2015.

[129] D. L. Oliveira, C. G. Freire-de-Lima, J. D. Nosanchuk, A. Casadevall, M. L. Rodrigues, and L. Nimrichter, "Extracellular vesicles from Cryptococcus neoformans modulate macrophage functions," Infection and Immunity, vol. 78, no. 4, pp. 1601-1609, 2010.

[130] P. C. Albuquerque, E. S. Nakayasu, M. L. Rodrigues et al., "Vesicular transport in Histoplasma capsulatum: an effective mechanism for trans-cell wall transfer of proteins and lipids in ascomycetes," Cellular Microbiology, vol. 10, no. 8, pp. 1695-1710, 2008.

[131] M. F. Goncalves, E. S. Umezawa, A. M. Katzin et al., "Trypanosoma cruzi: shedding of surface antigens as membrane vesicles," Experimental Parasitology emphasizes, vol. 72, no. 1, pp. 43-53, 1991.

[132] T. N. Bukong, F. Momen-Heravi, K. Kodys, S. Bala, and G. Szabo, "Exosomes from hepatitis C infected patients transmit $\mathrm{HCV}$ infection and contain replication competent viral RNA in complex with Ago2-miR122-HSP90," PLoS Pathogens, vol. 10, no. 10, Article ID e1004424, 2014.

[133] K. Tamai, N. Tanaka, T. Nakano et al., "Exosome secretion of dendritic cells is regulated by Hrs, an ESCRT-0 protein," Biochemical and Biophysical Research Communications, vol. 399, no. 3, pp. 384-390, 2010.

[134] C. Hsu, Y. Morohashi, S.-I. Yoshimura et al., "Regulation of exosome secretion by Rab35 and its GTPase-activating proteins TBC1D10A-C," The Journal of Cell Biology, vol. 189, no. 2, pp. 223-232, 2010.

[135] J. M. Silverman, J. Clos, E. Horakova et al., "Leishmania modulate innate and adaptive immune responses through effects on monocytes and dendritic cells," The Journal of Immunology, vol. 185, no. 9, pp. 5011-5022, 2010.

[136] E. Berrone, C. Corona, M. Mazza et al., "Detection of cellular prion protein in exosomes derived from ovine plasma," Journal of General Virology, vol. 96, no. 12, pp. 3698-3702, 2015.

[137] J. L. Kadurugamuwa and T. J. Beveridge, "Bacteriolytic effect of membrane vesicles from Pseudomonas aeruginosa on other bacteria including pathogens: Conceptually new antibiotics," Journal of Bacteriology, vol. 178, no. 10, pp. 2767-2774, 1996.

[138] Z. Li, A. J. Clarke, and T. J. Beveridge, "A major autolysin of Pseudomonas aeruginosa: Subcellular distribution, potential 
role in cell growth and division, and secretion in surface membrane vesicles," Journal of Bacteriology, vol. 178, no. 9, pp. 24792488, 1996.

[139] J.-F. Dubern and S. P. Diggle, "Quorum sensing by 2-alkyl4-quinolones in Pseudomonas aeruginosa and other bacterial species," Molecular BioSystems, vol. 4, no. 9, pp. 882-888, 2008.

[140] N. C. Kesty and M. J. Kuehn, "Incorporation of heterologous outer membrane and periplasmic proteins into Escherichia coli outer membrane vesicles," The Journal of Biological Chemistry, vol. 279, no. 3, pp. 2069-2076, 2004.

[141] A. J. McBroom and M. J. Kuehn, "Release of outer membrane vesicles by Gram-negative bacteria is a novel envelope stress response," Molecular Microbiology, vol. 63, no. 2, pp. 545-558, 2007.

[142] S. S. Thompson, Y. M. Naidu, and J. J. Pestka, "Ultrastructural localization of an extracellular protease in Pseudomonas fragi by using the peroxidase-antiperoxidase reaction," Applied and Environmental Microbiology, vol. 50, no. 4, pp. 1038-1042, 1985.

[143] S. R. Schooling and T. J. Beveridge, "Membrane vesicles: an overlooked component of the matrices of biofilms," Journal of Bacteriology, vol. 188, no. 16, pp. 5945-5957, 2006.

[144] N. C. Kesty, K. M. Mason, M. Reedy, S. E. Miller, and M. J. Kuehn, "Enterotoxigenic Escherichia coli vesicles target toxin delivery into mammalian cells," EMBO Journal, vol. 23, no. 23, pp. 4538-4549, 2004.

[145] S. M. van Dommelen, P. Vader, S. Lakhal et al., "Microvesicles and exosomes: opportunities for cell-derived membrane vesicles in drug delivery," Journal of Controlled Release, vol. 161, no. 2, pp. 635-644, 2012.

[146] P. Kharaziha, S. Ceder, Q. Li, and T. Panaretakis, “Tumor cell-derived exosomes: a message in a bottle," Biochimica et Biophysica Acta (BBA) - Reviews on Cancer, vol. 1826, no. 1, pp. 103-111, 2012.

[147] S. El Andaloussi, I. Mäger, X. O. Breakefield, and M. J. A. Wood, "Extracellular vesicles: biology and emerging therapeutic opportunities," Nature Reviews Drug Discovery, vol. 12, no. 5, pp. 347-357, 2013.

[148] J. Gao, D. Chu, and Z. Wang, "Cell membrane-formed nanovesicles for disease-targeted delivery," Journal of Controlled Release, vol. 224, pp. 208-216, 2016.

[149] B. Escudier, T. Dorval, N. Chaput et al., "Vaccination of metastatic melanoma patients with autologous dendritic cell (DC) derived-exosomes: results of the first phase 1 clinical trial," Journal of Translational Medicine, vol. 3, no. 1, article 10, 2005.

[150] M. A. Morse, J. Garst, T. Osada et al., "A phase I study of dexosome immunotherapy in patients with advanced non-small cell lung cancer," Journal of Translational Medicine, vol. 3, article 9, 2005.

[151] Y. Zhang, L. Li, J. Yu et al., "Microvesicle-mediated delivery of transforming growth factor $\beta 1$ siRNA for the suppression of tumor growth in mice," Biomaterials, vol. 35, no. 14, pp. 43904400, 2014.

[152] A. Tan, H. de la Peña, and A. M. Seifalian, "The application of exosomes as a nanoscale cancer vaccine," International Journal of Nanomedicine, vol. 5, no. 1, pp. 889-900, 2010.

[153] N. Kosaka, F. Takeshita, Y. Yoshioka et al., "Exosomal tumorsuppressive microRNAs as novel cancer therapy. "Exocure" is another choice for cancer treatment," Advanced Drug Delivery Reviews, vol. 65, no. 3, pp. 376-382, 2013.
[154] E. Iessi, M. Logozzi, L. Lugini et al., "Acridine orange/exosomes increase the delivery and the effectiveness of acridine orange in human melanoma cells: A new prototype for theranostics of tumors," Journal of Enzyme Inhibition and Medicinal Chemistry, vol. 32, no. 1, pp. 648-657, 2017.

[155] K. Kusuzaki, T. Matsubara, H. Murata et al., "Natural extracellular nanovesicles and photodynamic molecules: is there a future for drug delivery?" Journal of Enzyme Inhibition and Medicinal Chemistry, vol. 32, no. 1, pp. 908-916, 2017.

[156] M. Iero, R. Valenti, V. Huber et al., “Tumour-released exosomes and their implications in cancer immunity," Cell Death \& Differentiation, vol. 15, no. 1, pp. 80-88, 2008.

[157] A. M. Marleau, C.-S. Chen, J. A. Joyce, and R. H. Tullis, "Exosome removal as a therapeutic adjuvant in cancer," Journal of Translational Medicine, vol. 10, no. 1, article 134, 2012. 


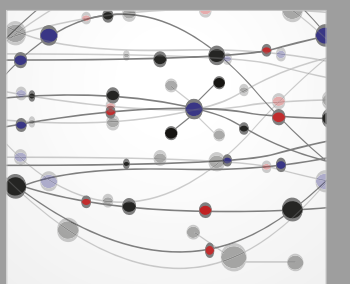

The Scientific World Journal
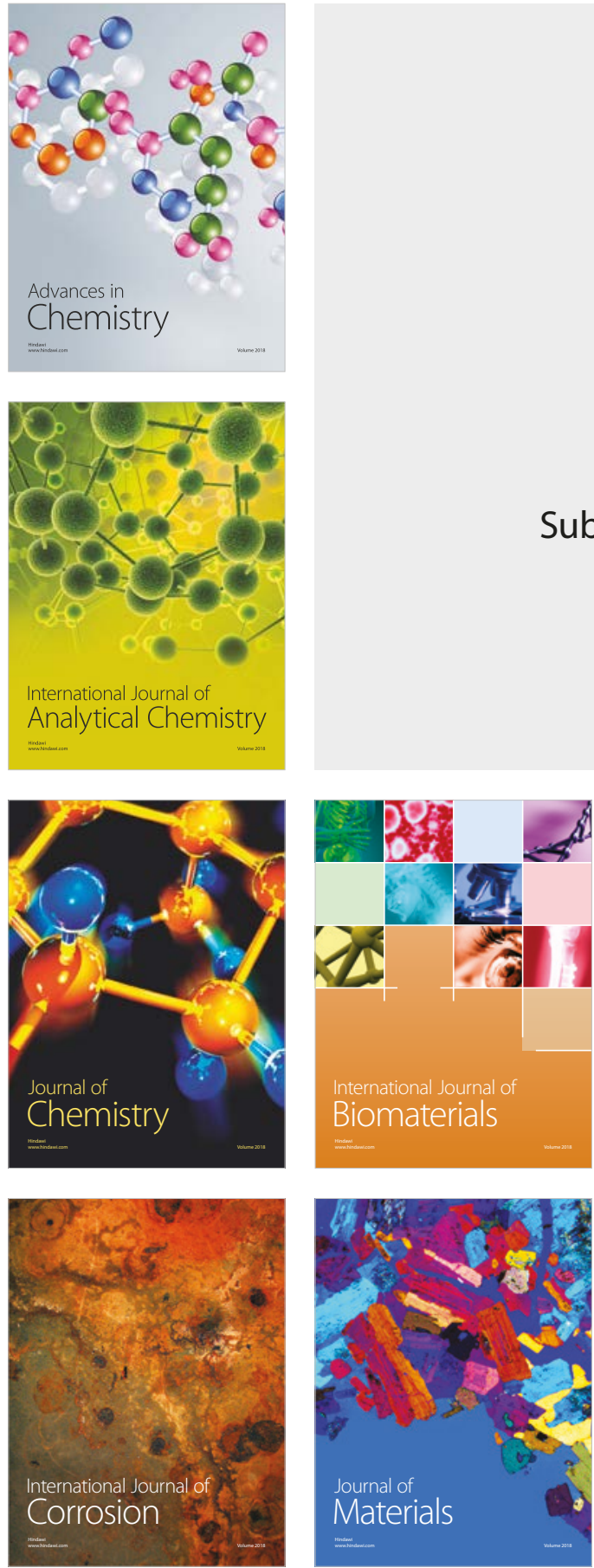

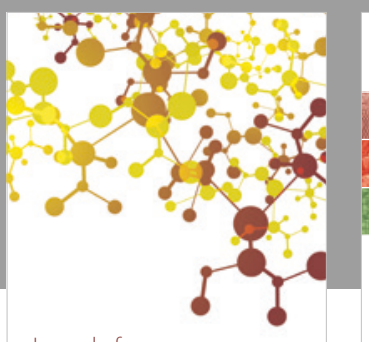

Journal of

Applied Chemistry
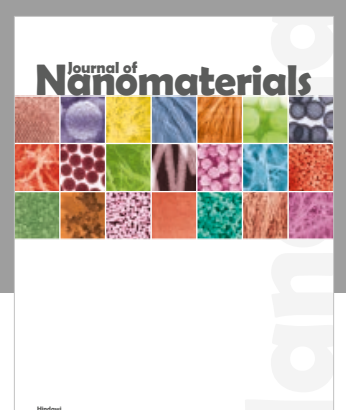

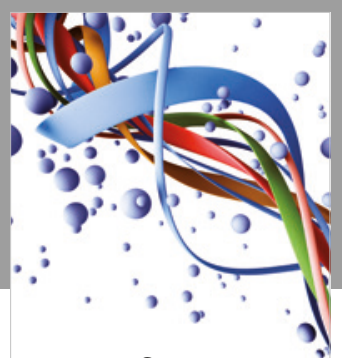

Scientifica

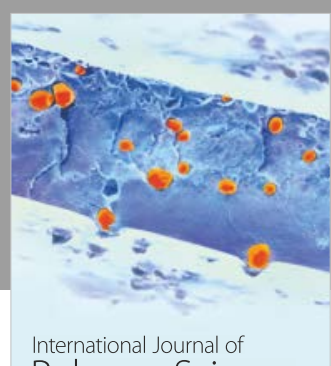

Polymer Science

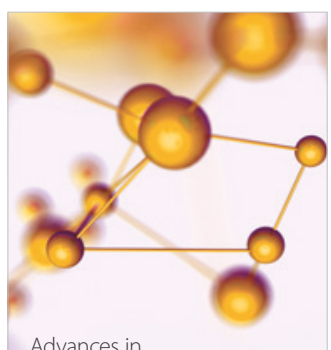

Physical Chemistry
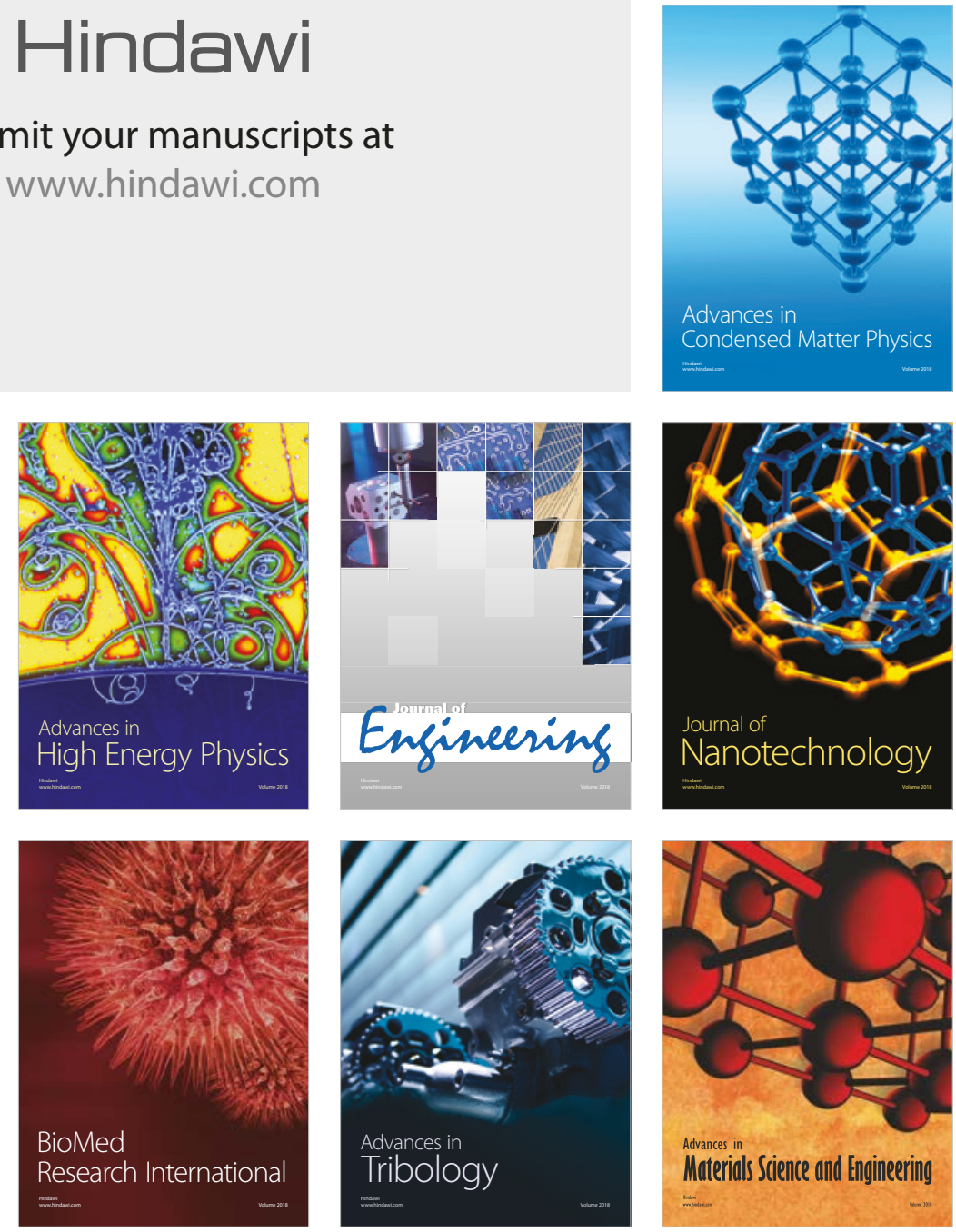